\title{
Carnivores (Mammalia) from areas of Nearctic-Neotropical transition in Puebla, central Mexico: presence, distribution, and conservation
}

\author{
Osvaldo Eric Ramírez-Bravo ${ }^{1,2 *}$ and Lorna Hernandez-Santin ${ }^{3}$ \\ 1 Durrell Institute for Conservation Ecology, Marlowe Building, University of Kent, Canterbury, Kent, CT2 7NR, England \\ 2 Departamento de Ciencias Químico-Biológicas, Universidad de las Américas, Puebla, Santa Catarina Mártir, Sin Número, Cholula, \\ Puebla. CP. 72820, México \\ 3 School of Biological Sciences, University of Queensland, Brisbane, St Lucia, QLD 4072, Australia \\ * Corresponding author. E-mail: ermex02@yahoo.com
}

\begin{abstract}
The Nearctic and Neotropical realms converge in central Mexico, where many areas have not been adequately characterized. Our objective was to revise the distribution and conservation status of carnivores in the state of Puebla, central Mexico. Between September 2008 and January 2011, we conducted interviews and fieldwork on seven previously selected areas. We complemented our data with bibliographical research. We obtained 733 records for 21 species, representing $63 \%$ of the carnivores reported for Mexico. We expanded known ranges of three species: Ocelot (Leopardus pardalis), Bobcat (Lynx rufus), and Tropical Ringtail (Bassariscus sumichastrii). Fifty percent of the carnivore species we recorded in Puebla are considered under some risk category. We found that carnivores in our study area are vulnerable to hunting pressure, humancarnivore conflicts that result in lethal control practices, and extensive habitat loss.
\end{abstract}

Key words: carnivores; distribution; corridor; conservation; Puebla

\section{INTRODUCTION}

The Nearctic and Neotropics are the two principal biogeographic regions present in the Americas (Ortega and Arita 1998; Morrone 2006). These two regions overlap in central Mexico, and for this reason, this area offers the opportunity to increase scientific understanding of species plasticity and distribution. However, this part of Mexico has not been adequately characterized, resulting in ambiguous descriptions of distributions of many species.

Puebla is one of the Mexican states where the Nearctic and Neotropical realms meet. Thus, Puebla contains a wide variety of habitats that range from semi-arid to tropical rain forest, including cloud forests, oak forests, pine forests, tropical dry forests, and xeric scrub (Ramírez-Pulido et al. 2005). Elevation in the region varies widely ranging from a minimum of $200 \mathrm{~m}$ on the coastal plains of the Gulf of Mexico up to a maximum of $5,700 \mathrm{~m}$ at the Pico de Orizaba, with abrupt variations on its four different mountain ranges (Ramírez-Pulido et al. 2005). These mountain ranges, including Sierra Norte and Mixteca, provide corridors of continuous habitat that potentially connect populations of a vast number of species, such as felids (Ramírez-Bravo et al. 2010). Nevertheless, mammals of Puebla are poorly studied compared to other states of Mexico (RamírezPulido et al. 2005). This means that there is limited information on statewide presence and distribution even of the medium and large-sized species belonging to the order Carnivora. Some of the studies on carnivores include two compilations: the first by Lopez-Wilchis and López-Jardines (1998) that accounts for specimens kept in collections in the United States and Canada. The second by Ramirez-Pulido et al. (2005) that examines distribution, taxonomy, and conservation status of carnivores in Puebla.

To improve scientific understanding of carnivore distribution in an area of biogeographic region overlap, our objective was to revise and update the distribution and conservation status of carnivores in Puebla, Mexico. Our study was based on new reports and field findings made throughout three years of fieldwork from the project "The Jaguar in Puebla: Presence and Human relations" and it is complemented with bibliographic data. 


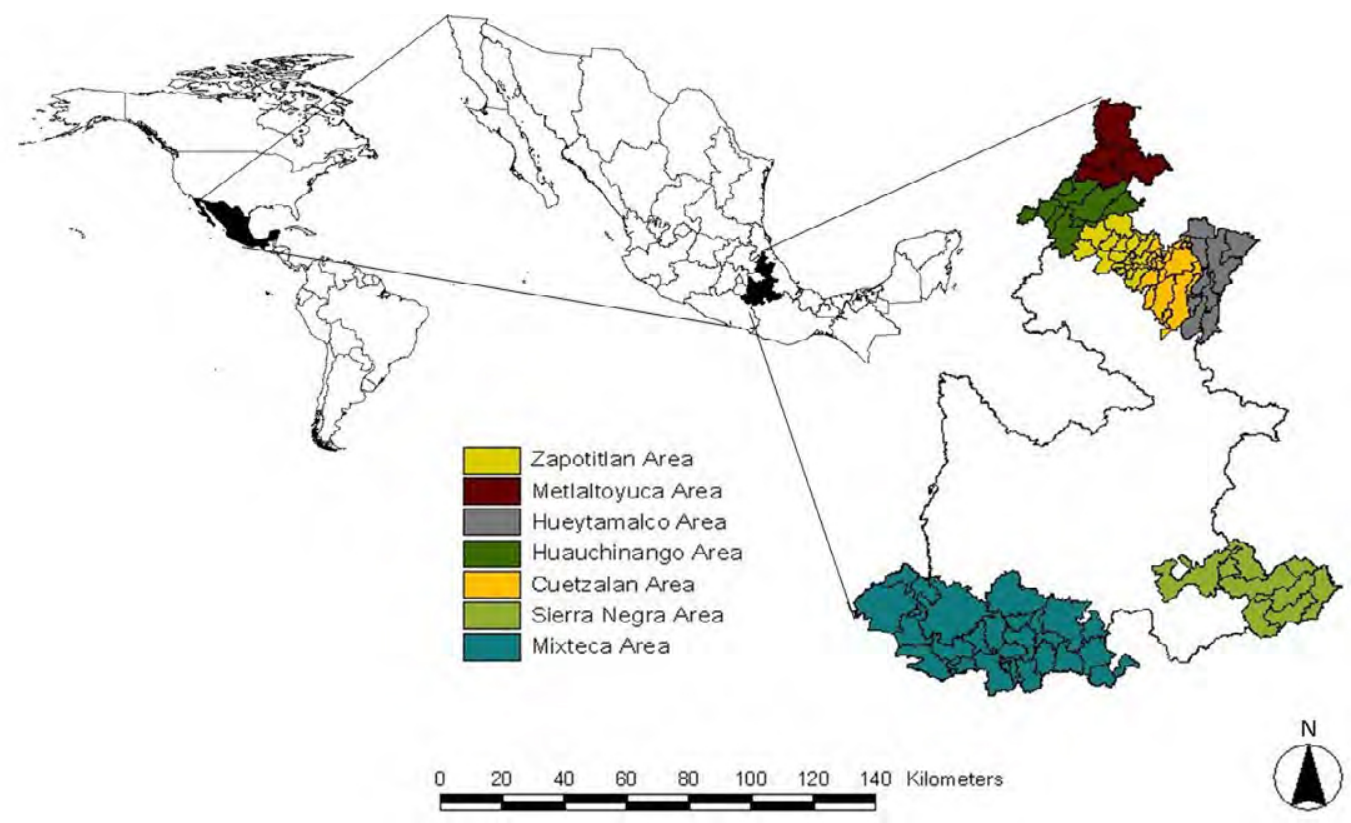

Figure 1. Survey areas in the state of Puebla, delimited according to their accessibility and connection with neighboring municipalities.

\section{MATERIALS AND METHODS Study area}

Seven study sites were previously selected based on the objectives of a long-term research project known as "The Jaguar in Puebla: Presence and Human relations" (Ramírez-Bravo et al. 2010). The selection process of the study sites was based on habitat suitability maps developed for Jaguars, based on environmental and anthropogenic variables (Ramirez-Bravo et al. 2010). These maps showed areas of high habitat suitability that were inferred to pose higher probability of Jaguar occurrence. Final selection of the seven sites was based on accessibility and connection with neighboring communities and municipalities (Figure 1). Five sites were located in northern Puebla along the Sierra Norte mountain range, one in the southwestern portion of the state along Mixteca, and one in the southwestern portion of the state along Tehuacan-Sierra Negra. Sierra Norte is characterized by relatively untouched vegetation that varied with elevation, including tropical forests (TF), cloud forests $(\mathrm{CF})$, oak forests $(\mathrm{OF})$, and pine forests $(\mathrm{PF})$. Mixteca is characterized by tropical deciduous forests (TDF) with patches of xeric scrub (XS). Tehuacán-Sierra Negra is characterized by xeric scrub intermixed with tropical deciduous forests, oak forests, cloud forests, and tall-treed tropical forests (TTF).

\section{Data collection}

We conducted interviews and fieldwork between September 2008 and January 2011 (Petracca et al. 2014). On arrival in a community, we interviewed local authorities, non-governmental organizations (NGOs), rancher associations, and people with different degrees of specialization and knowledge on local wildlife such as veterinarians, hunters, and other local people. During the first year, interviews were not structured; that is, we informally interviewed local people with different backgrounds aiming to identify presence and absence of different species in the region. From the second year onwards, we conducted formal interviews, using a pre-made datasheet. Structured interviews focused on determining how many days people spent in the field and the rate of sighting and/or sign encountering of Jaguars, their prey, and other carnivores. Analysis and details of interviewees' profiles can be found in (Petracca et. al. 2014). To allow the correct identification of species reported by interviewees, we used visual aids (pictures) during structured and unstructured interviews. That is, we showed them pictures of different medium-sized and large mammals that could inhabit the area, except skunks.

Besides interviews, sampling was supplemented by camera-trapping, scent station placing, and opportunistic records in areas close to the interviewed communities, including areas where locals had reported sightings (e.g., Petracca et. al. 2014). We set cameratraps along roads, trails, near bodies of water, and other sites with evidence of animal presence (Ramírez-Bravo et al. 2010). We used 23 camera-traps: Wildview Xtreme 4 (Texas, USA; $n=9$ ), Cuddeback (Wisconsin, USA; $n=4$ ), and Bushnell (Kansas, USA; $n=10$ ). We used one or two camera-traps per location and moved them every month to increase the area surveyed (Ramírez-Bravo et al. 2010). We placed scent stations in six vegetation patches in the area of Tehuacan-Sierra Negra from April to May 2010 and from October to December 2010. Given the heterogeneity of the area, we used a web arrangement instead of the typical line transect used by Sargeant et al. (2003). The latter as this trap arrangement has been proved effective to determine species distribution and 
patch usage in heterogeneous areas (Taki et al. 2007). In each study site, we set seven stations: one in the center and six forming an hexagon with a distance of $200 \mathrm{~m}$ from each station. We identified tracks using the field guide by Aranda (2000). Opportunistic evidence of presence included scats, tracks, and other sign that could indicate carnivore or prey presence. Tracks were transferred to acrylic casts and then to plastic bags. We collected scats in Tehuacán-Sierra Negra for another portion of a larger project that includes analyzing food habits. Scats found in Sierra Norte and Mixteca were only identified using external characteristics such as size and shape (Aranda 2000) and then photographed. Collection sites were georeferenced using a GPS device, and integrated into a statewide animal sign database that is currently under development.

To complement our fieldwork, we conducted a bibliographic research that included voucher-based published records (López-Wilchis and López Jardines 1998), mammal databases including the Mexican National Commission for Knowledge and Use of Biodiversity (CONABIO), published journal articles, and Bachelor theses from two local universities (Universidad de las Américas-Puebla, San Andres Cholula, Puebla) and Benemérita Universidad Autónoma de Puebla, Puebla,
Puebla). We subdivided all records by type, as indirect observations', 'signs', 'photographs', and 'interviews with physical evidence' that were records obtained from interviews (human accounts) accompanied by physical evidence (Appendix).

Finally, we developed a distribution map for each species using ArcView 3.2 (ESRI). We overlaid our records on a layer representing natural protected areas (Comisión Nacional de Áreas Naturales Protegidas 2011) with the distribution map for each species obtained from InfoNatura (InfoNatura 2007). When a record was located outside the known distribution of a given species, we measured the straight-line distance between the new record and the closest edge of the current known distribution.

\section{RESULTS AND DISCUSSION}

We surveyed 110 localities distributed throughout the seven survey-sites and obtained 519 records (Table 1 ). Of these, 156 correspond to field data and 363 to oral reports. Additionally, bibliographical research resulted in 214 records of carnivores in Puebla. Published reports contained 163 records within our study site (Table 1).

We increased the number of carnivores known to occur in Puebla from 18 (Ramírez-Pulido et al. 2005)

Table 1. List of carnivores present in Puebla, including their risk categories under different classifications and their evidence type recorded during this project. For each classification of risk category, we kept original acronyms and categories. The second column "SEM" represents those listed under the Official Mexican Norm, given by SEMARNAT (Diario Oficial, 2010): P (in danger of extinction), A (threatened), $\operatorname{Pr}$ (under special protection). The third column "CITES" corresponds to risk categories from CITES (UNEP-WCMC, 2011): Appendix SI (threatened), II (species that are not threatened but could become threatened without regulations on their commercialization), III (species included by a party that currently regulates that species commercialization and needs cooperation from other countries to avoid illegal non-sustainable exploitation). The fourth column "IUCN" represents risk categories from IUCN (IUCN, 2011): EN (endangered), DD (incomplete information), VU (vulnerable), and NT (nearly threatened). Columns 5 to 8 correspond to the type of evidence found during this project with the number of record locations in parenthesis: "DO" stands for direct observation, "S" for sign, " $\mathrm{P}$ " for photograph, and "AR" for additional record.

\begin{tabular}{|c|c|c|c|c|c|c|c|c|}
\hline \multirow[b]{2}{*}{ Common name } & \multirow[b]{2}{*}{ Species } & \multicolumn{3}{|c|}{ Risk category } & \multicolumn{4}{|c|}{ Evidence type } \\
\hline & & SEM & CITES & IUCN & DO & $\mathbf{S}$ & $\mathbf{P}$ & AR \\
\hline Jaguar & Panthera onca (Linnaeus, 1758) & $P$ & I & NT & & & & 4 \\
\hline Puma & Puma concolor (Linnaeus, 1771) & & ॥ & LC & & 1 & 1 & 6 \\
\hline Bobcat & Lynx rufus (Schreber,1777) & & & LC & & 6 & 1 & 13 \\
\hline Ocelot & Leopardus pardalis (Linnaeus, 1758) & $P$ & I & LC & 2 & 3 & 1 & 11 \\
\hline Jaguarundi & Puma yagouaroundi (Lacépède, 1809) & $A$ & 1 & LC & 2 & & 1 & 4 \\
\hline Margay & Leopardus wiedii (Schinz, 1821) & $P$ & 1 & NT & 8 & & 2 & 6 \\
\hline Coyote & Canis latrans (Say, 1823) & & & LC & 3 & 6 & 4 & 19 \\
\hline Grey fox & Urocyon cinereoargnteus (Schreber, 1775) & & & LC & 7 & 4 & 8 & 11 \\
\hline Badger & Taxidea taxus (Schreber, 1778) & $A$ & & LC & & 1 & & 3 \\
\hline Otter & Lontra longicaudis (Olfers, 1818) & A & I & DD & 1 & & & 7 \\
\hline Tayra & Eira barbara (Linnaeus, 1758) & $\mathrm{P}$ & III & LC & & & & 3 \\
\hline Grison & Galictis vittata (Schreber, 1776) & A & III & LC & 2 & & & 1 \\
\hline Long-tailed weasel & Mustela frenata (Lichtenstein, 1831) & & & LC & & 5 & & 16 \\
\hline Hooded skunk & Mephitis macroura (Lichtenstein, 1832) & & & LC & & 4 & 4 & 13 \\
\hline Spotted skunk & Spilogale putorius (Linnaeus, 1758) & & & LC & & & & 3 \\
\hline Eastern hog-nosed skunk & Conepatus leuconotus (Lichtenstein, 1832) & & & LC & 1 & 3 & 5 & 9 \\
\hline Coati & Nasua narica (Linnaeus, 1766) & & & LC & 9 & & 11 & 10 \\
\hline Ringtail & Bassariscus astutus (Lichtenstein, 1830) & A & & LC & 2 & 6 & 3 & 27 \\
\hline Tropical ringtail & Bassariscus sumichastrii (Saussure, 1860) & $\operatorname{Pr}$ & & LC & & & & 1 \\
\hline Kinkajou & Potos flavus (Schreber, 1774) & $\operatorname{Pr}$ & III & LC & 6 & & & 2 \\
\hline Racoon & Procyon lotor (Linnaeus, 1758) & & & LC & 6 & 5 & 11 & 9 \\
\hline
\end{tabular}


to 21 species, adding the Jaguar (Panthera onca), Ocelot (Leopardus pardalis), and Tropical Ringtail (Bassariscus sumichrastri). Puebla has $63 \%$ of the carnivore species recorded from Mexico. Our findings confirm the high biodiversity of the state that has been previously noted (CONABIO 2011). In fact, the Tehuacán-Cuicatlán Biosphere Reserve (located within Tehuacan-Sierra Negra) has the fifth highest mammal diversity in Mexico after tropical rainforest reserves (Ramírez-Pulido and Martinez Vázquez 2007). Our updated distribution maps expand the distribution of three species: Ocelot (Leopardus pardalis), Bobcat (Lynx rufus), and Tropical Ringtail (Bassariscus sumichrasti) (Appendix). The distribution of Ocelot is expanded northwards by $51 \mathrm{~km}$ into Mixteca. The distribution of Bobcat is expanded northward by $56 \mathrm{~km}$ in Sierra Norte. There was a report of a female Tropical Ringtail collected in Mixteca in 1970 (López-Wilchis and López-Jardines 1998). We expand the distribution of tropical ringtail $86 \mathrm{~km}$ north into Mixteca.

Eleven of the 21 species we found are listed under some kind of risk category (SEMARNAT 2010). Four are listed as endangered, five are as threatened, and two are under special protection (Table 1), which means that $50 \%$ of the carnivore species in Puebla are under some risk category. In general, carnivores are vulnerable to human-carnivore conflicts, and to habitat loss (Woodroffe and Ginsberg 1998). This holds true in our study area. Hunting has been reported in several regions of Puebla (Ramírez-Pulido et al. 2005). Human-carnivore issues result in control practices such as poisoning, which interviewees admitted as a common practice aimed at eliminating some species, such as Coyotes (Canis latrans) and Coatis (Nasua narica), from agricultural areas. Habitat loss has been high in some regions such as Sierra Norte (Evangelista et al. 2010).

Most of the carnivore records were outside protected areas and were more frequent in forest fragments (see maps in Appendix). Thus, it is imperative to revise the natural preserve network to improve carnivore conservation in Puebla and to include habitats that have not yet been protected. In addition, more efforts should be made to involve local people in sustainableuse practices that aid carnivore conservation outside of protected areas.

\section{ACKNOWLEDGEMENTS}

We thank National Geographic Society who provided funding necessary to launch the Project during 2008-2009, to the Panthera organization, which gave support for our work in the north of Puebla during 2010, and to the Durrell Wildlife Conservation Trust, which provided funds for fieldwork in the TehuacanSierra Negra region during 2011. We also acknowledge the Departamento de Ciencias Químico Biológicas de la Universidad de las Américas, Puebla for providing access to their facilities and other support during this project. Moreover, we would like to thank each municipality for providing all the information about the situation within their territories. Special thanks go to the Oficina de Turismo in Hueytamalco and to regiduría de Ecología de Cuetzalan del Progreso. We thank the association ARS de la Mixteca, A.C., the Tehuacán Cuicatlán biosphere reserve, the Natural Protected Area of Cuenca Hidrológica Río Necaxa, Ecoturismo Ixkit, Ojo de Agua, and Xochiquetzal for giving us the support to carry out this project. We hope to have the support of local communities that will allow us to continue with the project. We would also like to thank all the institutions that have supported us throughout these two years and to the people who have so kindly answered our interviews within their jobs, associations, and communities. Finally, we would like to thank the anonymous referees and the editor for the valuable commentaries and suggestions.

\section{LITERATURE CITED}

Álvarez, T. and A. Ocaña. 1999. Sinopsis de restos arqueozoológicos de vertebrados terrestres. Basada en informes del Laboratorio de Paleozoología del INAH: Instituto de Antropología e Historia, Colección Científica 386: 108 pp.

Aranda M. 200o. Huellas y otros rastros de los mamíferos Grandes y Medianos de México. Instituto de Ecología, A.C., Xalapa, Veracrúz, México. 212 pp.

Bassols Batalla., I. 1981. Catálogo de los ácaros Mesostigmata de mamíferos de México. Anales de la Escuela Nacional de Ciencias Biológicas, México, 2(1): 9-49.

Clevenger, A.P., J. Wierzchowski, B. Chruszcz, and K. Gunson. 2002. GIS-generated, expert-based models for identifying wildlife habitat linkages and planning mitigation passages. Conservation Biology 16(2): 503-514. doi: 10.1046/j.1523-1739.2002.00328.x

Comisión Nacional de Áreas Naturales Protegidas. 2011. Cobertura de las Áreas Naturales Protegidas Federales de México. Comision de Áreas Naturales Protegidas, México D. F., Mexico. Accessed at http://sig.conanp.gob.mx/website/pagsig/imgmapoteca/FAD/, 5 October 2011

COTEIGEP (Comité Estatal de Información Estadística y Geográfica des Estado de Puebla). 2011. Mapas estatales de rasgos físicos del Estado de Puebla. Accessed at http://www.coteigep.puebla.gob. $\mathrm{mx}, 20$ October 2011.

Diario Oficial. 2010. Protección ambiental-Especies nativas de México de flora y fauna silvestres-Categorías de riesgo y especificaciones para su inclusión, exclusión o cambio-Lista de especies en riesgo Norma Oficial Mexicana NOM-059-SEMARNAT-2010, Mexico D.F.

Escalante, T., G. Rodríguez-Tapia, C. Szumik, J.J. Morrone and M. Rivas. 2010. Delimitation of the Nearctic region according to mammalian distributional patterns. Journal of Mammalogy 9(6): 1381-1388. doi: 10.1644/10-MAMM-A-136.1

Evangelista-Oliva, V., J. López-Blanco, J. Caballero-Nieto and M.A. Martínez-Alfaro. 2010. Patrones espaciales de cambio de cobertura y uso del suelo en el área cafetalera de la Sierra Norte de Puebla. Investigaciones Geográficas, Boletín del Instituto de Geografía 72(1): 23-38. http://www.redalyc.org/articulo.oa?id=56919174003

Ferrari-Pérez, F. 1886. Catalogue of animals collected by the Geographical and Exploring Commission of the Republic of Mexico. Proceedings of the U. S. National Museum 9 (559): 125-199. http://biodiversitylibrary.org/page/7600770 
Gallo-Reynoso, J.P. 1997. Situación y distribución de las nutrias en México, con énfasis en Lontra longicaudis annectens Major, 1897. Revista Mexicana de Mastozoología 2(1): 10-32 url: http:// revistamexicanademastozoologia.com.mx/ojs/index.php/rmm/ article/view/70

Goldman, E.A. 1938. List of the gray foxes of Mexico. Journal of the Washington Academy of Sciences 28(11): 494-498. http:// biodiversitylibrary.org/page/39691275

Hall, E.R. 1981. The mammals of North America, $1^{\text {st }}$ edition, Vol. 2: 601-1181. New York: John Wiley and Sons.

Hall, E.R. and W.W. Dalquest. 1950. Geographic range of the hooded skunk, Mephitis macroura, with description of a new subspecies from Mexico. University of Kansas Publications, Museum of Natural History 1(24): 575-580. http://biodiversitylibrary.org/ page/2807490

Hoffmann, A., I. Bassols, and C. Méndez. 1972. Nuevos hallazgos de ácaros en México. Revista de la Sociedad Mexicana de Historia Natural 33(): 151-159. http://hdl.handle.net/11154/143261

InfoNatura. 2007. Aves, Mamíferos y Anfibios de América Latina: Webpage application, [version 5.0]. Accessed at http://www. natureserve.org/infonatura, 5 October 2011.

Ingles, L. G. 1959. Notas acerca de los mamíferos mexicanos. Anales del Instituto de Biología, Universidad Nacional Autónoma de México 29: 379-408.

IUCN (International Union for the Conservation of Nature). 2011. 2011 IUCN Red List of threatened species. Accessed at http:// www.iucnredlist.org, 30 Cctober 2011

Jackson, H.H.T. 1951. Classification of the races of the coyote. Pp. 227-341, in: S.P. Young and H.H.T. Jackson. The clever coyote. Washington, D.C/Harrisburg, PA: The Stackpole Co./Wildlife Management Institute.

Long, C.A. 1972. Taxonomic revision of the North American Badger, Taxidea taxus. Journal of Mammalogy 53(4): 725-759. doi: 10.2307/1379211

López-Wilchis, R. and J. López Jardines. 1998. Los mamíferos de México depositados en colecciones de Estados Unidos y Canada. Mexico: Universidad Autónoma Metropolitana Unidad Iztapalapa. $323 \mathrm{pp}$.

Merriam, C.H. 1897. Revision of the coyotes or prairie wolves, with descriptions of new forms. Proceedings of the Biological Society of Washington 11(1): 19-33. http://biostor.org/reference/82756

Morrone, J.J. 2006. Biogeographic areas and transition zones of Latin America and the Caribbean Islands based on panbiogeographic and cladistic analyses of the entomofauna. Annual Review of Entomology 51(1): 457-494. doi: 10.1146/ annurev.ento.50.071803.130447

Ortega, J. and H.T. Arita. 1998. Neotropical-Nearctic limits in Middle America as determined by distributions of bats Journal of Mammalogy 79(3): 772-783. doi: 10.2307/1383088

Petracca, L., O.E. Ramírez-Bravo and L. Hernández-Santin. 2014. Evaluation of a potential corridor for Jaguars (Panthera onca) in a community dominated landscape in Central Mexico. Oryx 48(1): 133-140. doi: 10.1017/So030605310001353

Ramírez-Bravo, O.E. 2010. Neotropical otter (Lontra longicaudis) records in Puebla, Central Mexico. Otter Specialist Group Bulletin 27(3): 134-136. http://www.otterspecialistgroup.org/ Bulletin/Volume27/Bravo_2010.html

Ramírez-Bravo, O.E. 2011. New records of Tayra (Eira barbara Linnaeus 1758) in Puebla, Central Mexico. Acta Zoológica Mexicana (n.s.) 27(3): 883-886. http://www.redalyc.org/articulo. oa?id $=57521382024$

Ramírez-Bravo, O.E and E. Bravo. 2010. Notes on Puma (Puma concolor), Lynx (Lynx rufus), Margay (Leopardus wiedii) and Jaguarundi (Puma yagouaroundi) distribution in Puebla, Central Mexico. Wild Felid Monitor 3(1): 20.

Ramírez-Bravo, O.E., E. Bravo Carrete, S. Schinkel Brault, C. Hernández Santín, and C. Kinner. 2010a. Ocelot (Leopardus pardalis) distribution in the state of Puebla. Therya 1(1): 111-120. http://www.mastozoologiamexicana.org/therya/volinum2/312-Ramirez-3.pdf

Ramírez-Bravo, O.E., S. Schinkel Brault, and C. Hernández Santín. 2010b. Nuevo registro de Ocelote (Leopardus pardalis) para el estado de Puebla. Therya 1(1): 63-65. http://www.mastozoologia mexicana.org/doi/10.12933/therya-10-9/therya-10-9

Ramírez-Pulido, J., N. González-Ruiz and H.H. Genoways. 2005. Carnivores from the Mexican state of Puebla: distribution, taxonomy and conservation. Mastozoología Neotropical 12(1): 37-52. http://www.redalyc.org/articulo.oa?id $=45712104$

Ramírez Pulido, J. and J. Martínez Vázquez. 2007. Diversidad de los mamíferos de la Reserva de la biósfera Tehuacán-Cuicatlán, Puebla-Oaxaca, México. Mexico: CONABIO. Informe final SNIBCONABIO proyecto No. BKo22.

Sargeant, G.A., D.H. Johnson and W.E. Berg. 2003. Sampling designs for carnivore scent-station surveys. Journal of Wildlife Management 67(2): 289-298. doi: 10.2307/3802770

Taki, H., B.F. Viana, P.G.Kevan, F.O. Silva and M. Buck. 2007. Does forest loss affect the communities of trap-nesting wasps (Hymenoptera: Aculeata) in forests? Landscape vs. local habitat conditions. Journal of Insect Conservation 12(1): 15-21. doi: 10.1007/s10841-006-9058-1

UNEP-WCMC (United Nations Environment Programme's World Conservation Monitoring Centre). 2011. UNEP-WCMC Species Database: CITES-Listed Species. Accessed at http://www.cites. org, 10 October 2011.

Urbano, V.G., H, O. Sánchez, G.G. Téllez, and R.A. Medellín. 1987. Additional records of Mexican mammals. The Southwestern Naturalist 32(1): 134-137. http://www.jstor.org/stable/3672020

Van Gelder R.G. 1960. Carnivores in Puebla, Mexico. Journal of Mammalogy 41(3): 519. doi: 10.2307/1377556

Villarreal Espino-Barros, O.A., R. Guevara-Viera, R. ReséndizMartínez, J.S. Hernández-Zepeda, J. C. Castillo-Correo, and F.J. Tomé-Torres. 2005. Diversificación productiva en campo experimental Las Margaritas, Puebla, México. Archivos Zooctecnológicos 54(206): 197-203. http://www.redalyc.org/ pdf/495/49520713.pdf

Warner, D. W. and J. R. Beer. 1957. Birds and mammals of the Mesa de San Diego, Puebla, Mexico. Acta Zoológica Mexicana 2: 1-21.

Wieczorek, J. 2001. Mammal Network Information System MaNIS. University of California, Berkeley. Accessed at http://manisnet. org/manis/index.html, 31 October 2011

Woodroffe, R. and J.R. Ginsberg. 1998. Edge effects and the extinction of populations inside protected areas. Science 280(5372): 21262128. doi: 10.1126/science.280.5372.2126

Zeller, K. 2007. Jaguars in the new millennium data set update: the state of the Jaguar in 2006. New York: Wildlife Conservation Society.

Received: 26 November 2012

Accepted: 15 January 2016

Academic editor: Guilherme Siniciato Terra Garbino 


\section{APPENDIX}

\section{Distribution maps and species records found} during our study

Here we present species records subdivided by type. Thus, records obtained through physical evidence, mainly skins and mounted specimens appear under "direct observation", records made from indirect observation such as tracks, scats, and scrapes are listed under "sign", under "photograph" we listed pictures taken using camera-traps are unless stated otherwise, and "additional records" refers to those found from bibliographical research. Records obtained from interviews (human accounts) without physical evidence are not considered in these maps. The number of records is given in parenthesis, following the category, location, or source where each record was found. We attached a map of the records and potential distribution from InfoNatura (2007) for each species to compare them with reported distribution.

\section{Family Felidae}

\section{Panthera onca (Linnaeus, 1758)}

Common names: Jaguar, Tigre

Additional records (5): Sierra Norte (4), Sierra Negra (1). Zapotitlán de Mendez, Barranca de Necaxa, Metlaltoyuca (Ramírez-Bravo 2011) (3) Hueytamalco (Villareal et al. 2005), and Ojo de Agua Dulce (Zeller 2007) (1). This species presented a few records limited to the tropical areas of the study areas in the state (Figure A1).

Puma concolor (Linnaeus, 1771)

Common names: Puma, Mountain Lion, León

Sign (1): Sierra Norte. We found a track mold made by a local hunter (ca. 1995), in TF near the community Telotla (Figure A2).
Photograph (1): Sierra Norte. This record is a photograph of a juvenile puma, hunted in $\mathrm{CF}$ near the community Xicotepec (ca. 2001) (Figure A2).

Additional records (6): Mixteca (1), Sierra Norte (3), Tehuacan-Sierra Negra (1), and Valle (1). San José Alchichica (Ramírez-Pulido et al. 2005), Naupan, Huauchinango, Tlaxco, Tehuacán, and Santa Ana Tecolapa (Ramírez-Bravo 2010) (Figure A2).

\section{Lynx rufus (Schreber, 1777)}

Common names: Gato montés, Bobcat

Sign (6): Mixteca, Sierra Norte, Tehuacan-Sierra Negra (4). We found tracks at the edge of a dry creek in TDF near Agua Dorada (Mixteca) during January 2011. In Hueyapan (Sierra Norte with P-OF) we found tracks along a slightly used trail; this record expands the known species distribution $56 \mathrm{~km}$ to the north. The signs from Tehuacan-Sierra Negra (Ajalpan, San Esteban Necoxcalco, San Diego Chalma, and Corral Macho) are located near the biosphere preserve Tehuacán-Cuicatlán. In this area people said that the species is uncommon in the area, possibly due to placement of poison aimed for feral dogs (Figure $\mathrm{A}_{3}$ ).

Photograph (1): Mixteca. It was taken on an unused trail on TDF with patches of Acacia forest near Chiautla de Tapia (Figue $\mathrm{A}_{3}$ ).

Additional records (13): Mixteca (1), Sierra Norte (5), Tehuacan-Sierra Negra (3), and Valle (3). Texcal; Tepeyolo (Álvarez \& Ocaña 1999); San Martín Texmelucan (Ferrari-Pérez 1886), San José Alchichica (Ramírez-Pulido et al. 2005), Tepeyoloc (unpublished data), Xicotepec de Juárez, Huauchinango, Caxhuacán, Ciudad de Cuetzalán, Hueytamalco, Santa Ana Tecolapa, Tehuacán (Ramírez-Bravo 2010); and Los Humeros (unpublished data) (Figure $\left.\mathrm{A}_{3}\right)$.

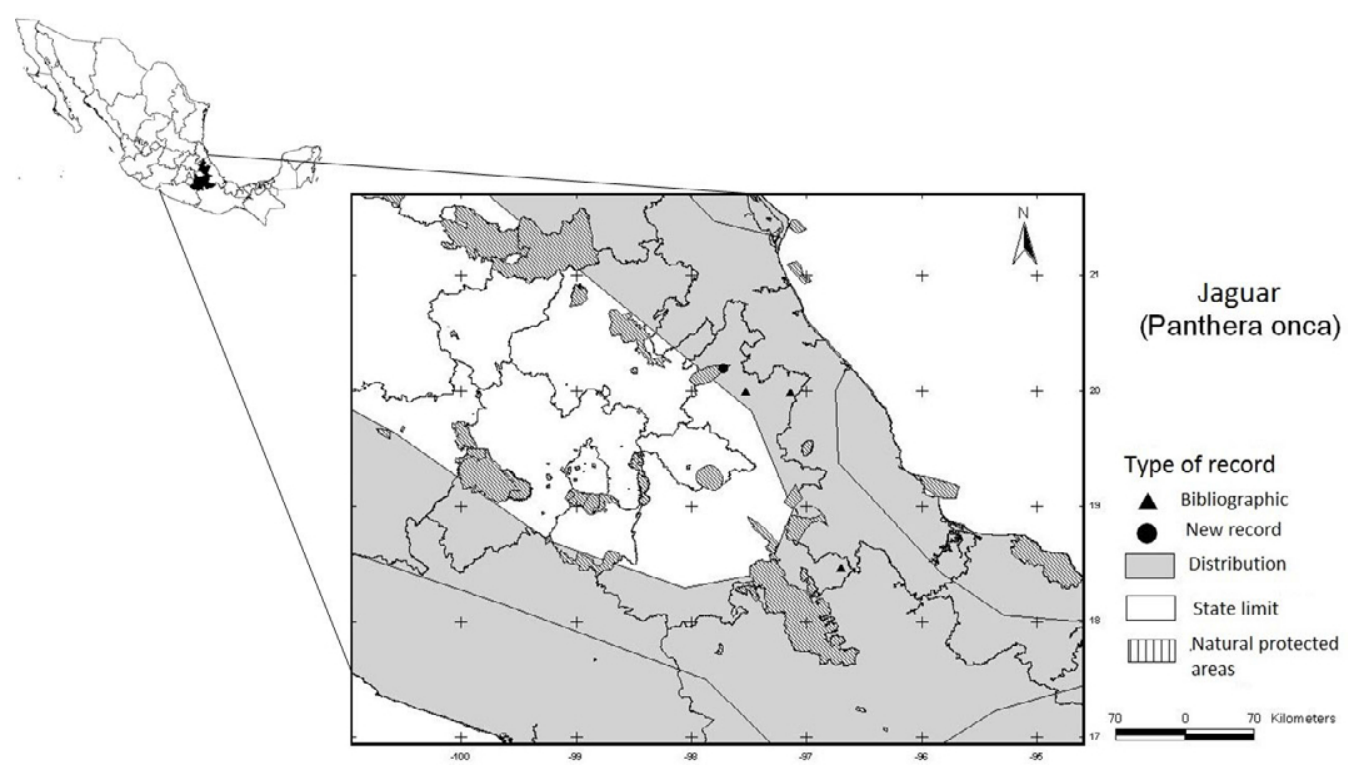

Figure A1. Jaguar records in the state of Puebla and distribution obtained from InfoNatura (2007). 


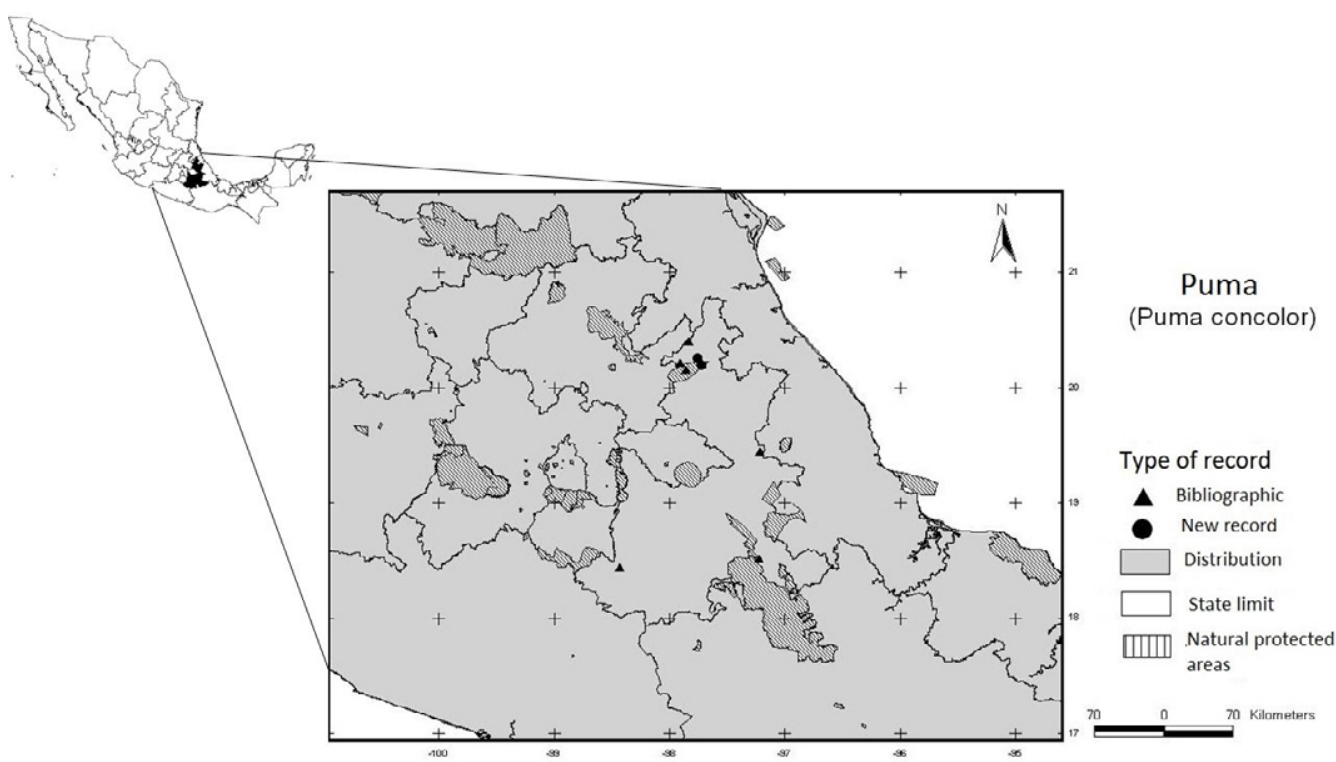

Figure A2. Puma records in the state of Puebla and distribution obtained from InfoNatura (2007).

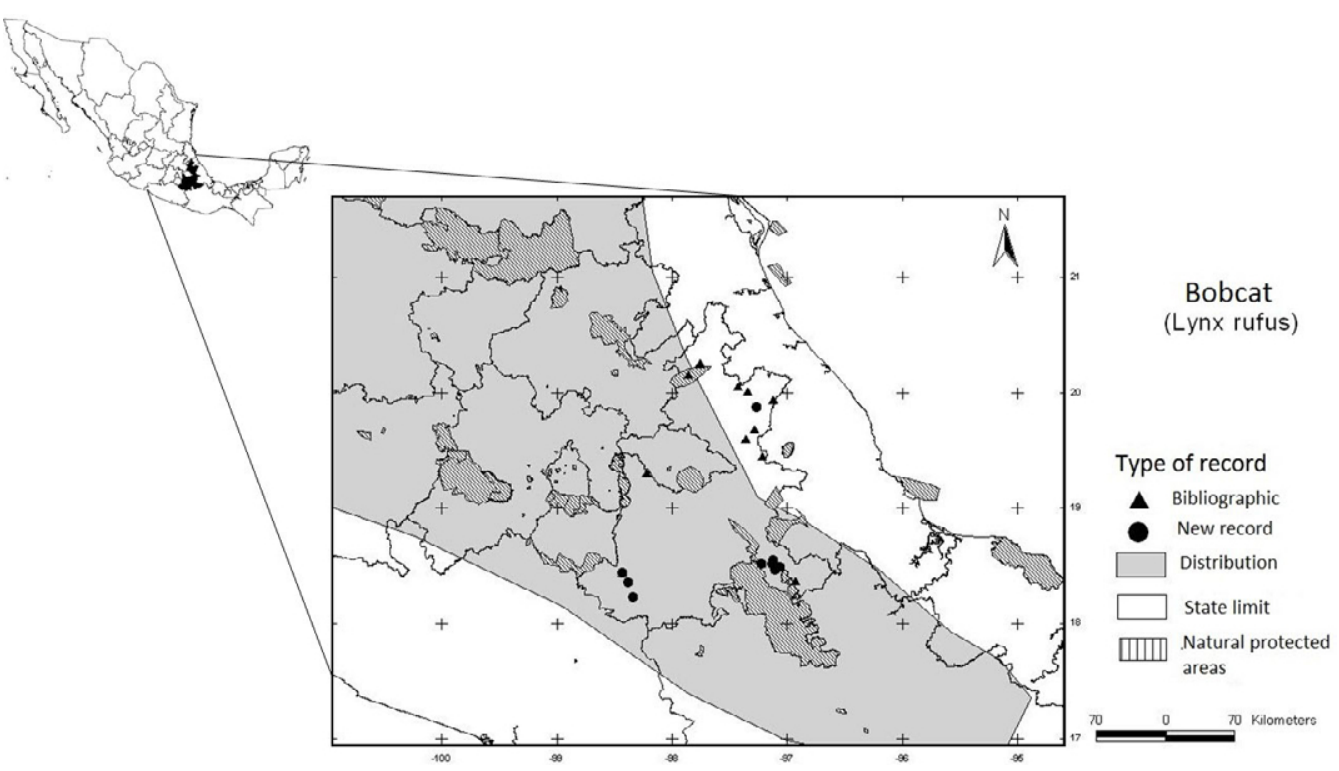

Figure 3. Bobcat records in the state of Puebla and distribution obtained from InfoNatura (2007).

Leopardus pardalis (Linnaeus, 1758)

Common name: Ocelote, Ocelot

Direct observation (2): Sierra Norte. We found skins owned by hunters. The first was hunted near Villa Lázaro Cárdenas where the coastal prairies are dominated by agricultural areas with patches of TF. The second, found in Cuetzalán, was collected on CF; however, it is an old record and its collection date remains uncertain (Figure A4).

Sign (3): Sierra Norte (2), Tehuacan-Sierra Negra. We found tracks near water bodies in TF of Sierra Norte (one near Telolotla, the other near Tecomate), and in TDF from Tehuacan-Sierra Negra (near Corral Macho) (Figure $\mathrm{A}_{4}$ ).

Photograph (1): Sierra Norte. We camera-trapped an adult male in Sierra Norte (near Vega Chica) in TF.

Aditional Records (12): Mixteca (2), Sierra Norte (8), Tehuacan-Sierra Negra (1), and Valle (1). Las Margaritas
(Villareal et al. 2005), Chiautla de Tapia (López-Wilchis and López-Jardines 1999), Huauchinango, Xicotepec, La Unión, Jopala, Huehuetla, Plan de Guinea, Tehuacán, Santa Ana Tecolapa (Ramírez-Bravo et al. 2010 a), and Hueytamalco, (Ramírez-Bravo et al. 2010 b). It is noteworthy that additional records made by RamirezBravo et al. (2010b) in Mixteca, more specifically those found near San Ana Tecolapa (TDF) contribute to the expansion of the species current known distribution by $51 \mathrm{~km}$ to the north of Guerrero state.

\section{Herpailurus yagouaroundi (Lacépède, 1809)}

Common name: Jaguarundi

Direct observation (2): Mixteca, Sierra Norte. We found two unsexed mounted specimens: one in Chiautla de Tapia (Mixteca) and the other with unknown date of collection in Villa Lázaro Cárdenas (Sierra Norte) (Figure $\mathrm{A}_{5}$ ). 


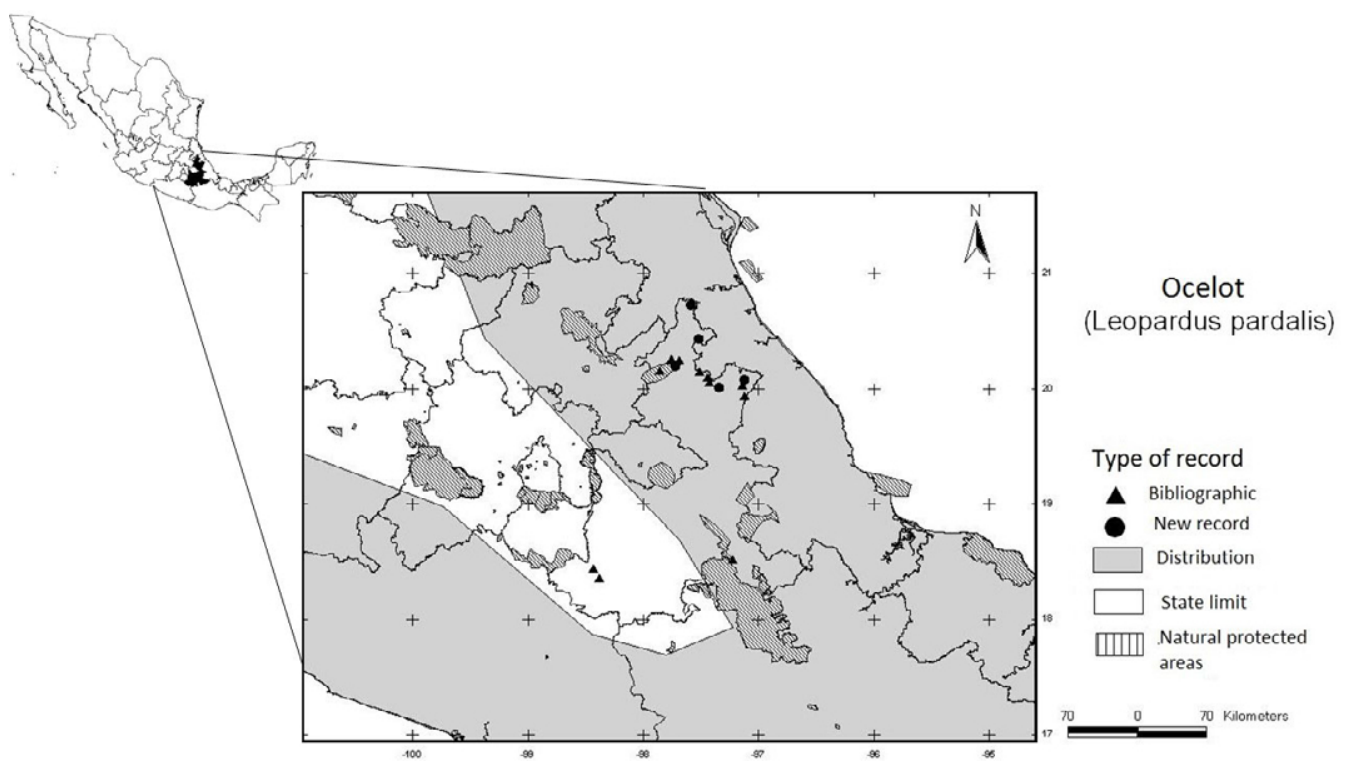

Figure A4. Ocelot records in the state of Puebla and distribution obtained from InfoNatura (2007).

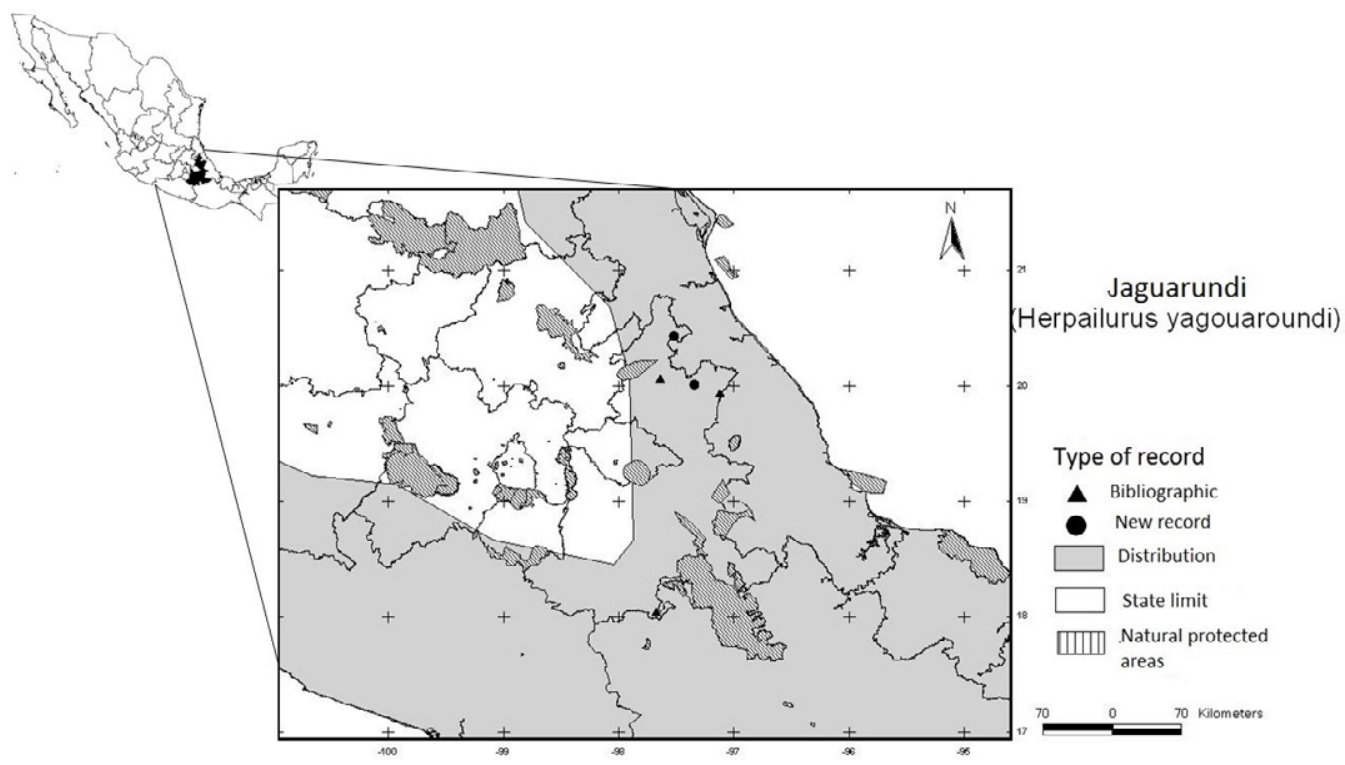

Figure A5. Jaguarundi records in the state of Puebla and distribution obtained from InfoNatura (2007).

Photographs (1): Sierra Norte. The picture was taken by a tourist in CF near Cuetzalán in November 2010. The municipality's councilor of ecology gave us the picture later on that same month (Figure A5).

Additonal records (4): Mixteca (1) and Sierra Norte (3). Ocotal, Hueytamalco, (Ramírez-Pulido et al. 2005), Hueytamalco (Urbano-Vidales et al.1987), and Chila de las Flores (unpublished data).

\section{Leopardus wiedii (Schinz, 1821)}

Common name: Tigrillo

Direct observation (8): Sierra Norte. These records correspond to skins, mounted specimens, and one kept as pet in communities found in a stretch of $\mathrm{TF}$ and $\mathrm{CF}$ (Figure A6).

Photographs (2): Sierra Norte. We caught L. weidii several times during nights in January and June 2010 near the community Telolotla, another one was photographed during July near the community of El Tecomate (Figure A6).

Aditional records (6): Mixteca (1), Sierra Norte (4), and Tehuacan-Sierra Negra (1). Olintla, Ocotal (RamírezPulido et al. 2005); Santa Ana Tecolapa, Coxcatlán, Caxhuacán, and Huauchinango (Ramírez-Bravo 2010) (Figure A6).

Family Canidae

\section{Canis latrans (Say, 1823)}

Common name: Coyote

Direct observation (3): Mixteca, Sierra Norte, Tehuacan-Sierra Negra. These records are skins; the one we found in Mixteca (near Santa Ana Tecolapa) was hunted on December 2010 in TDF with moderate perturbation. The one in Sierra Norte (near Olintla) occurred in patches of TDF. Moreover, we found 


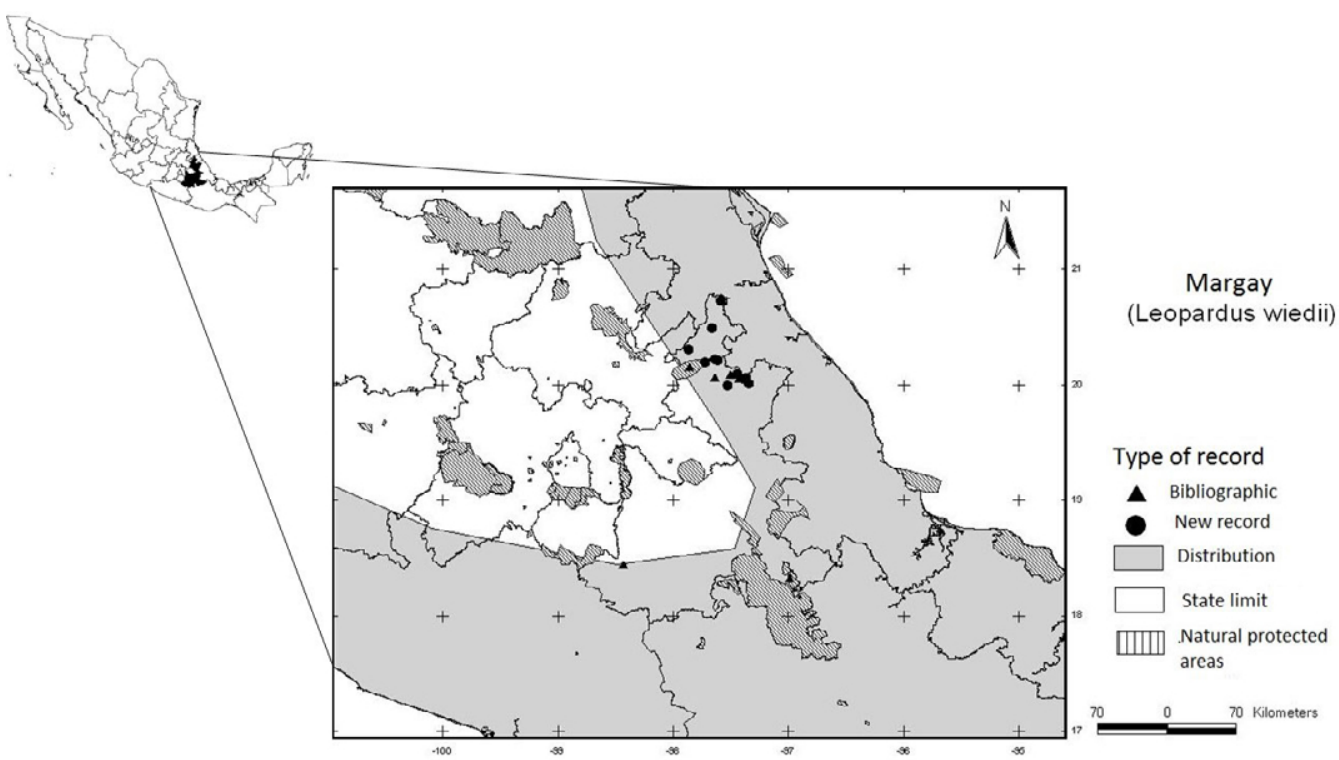

Figure A6. Margay records in the state of Puebla and distribution obtained from InfoNatura (2007).

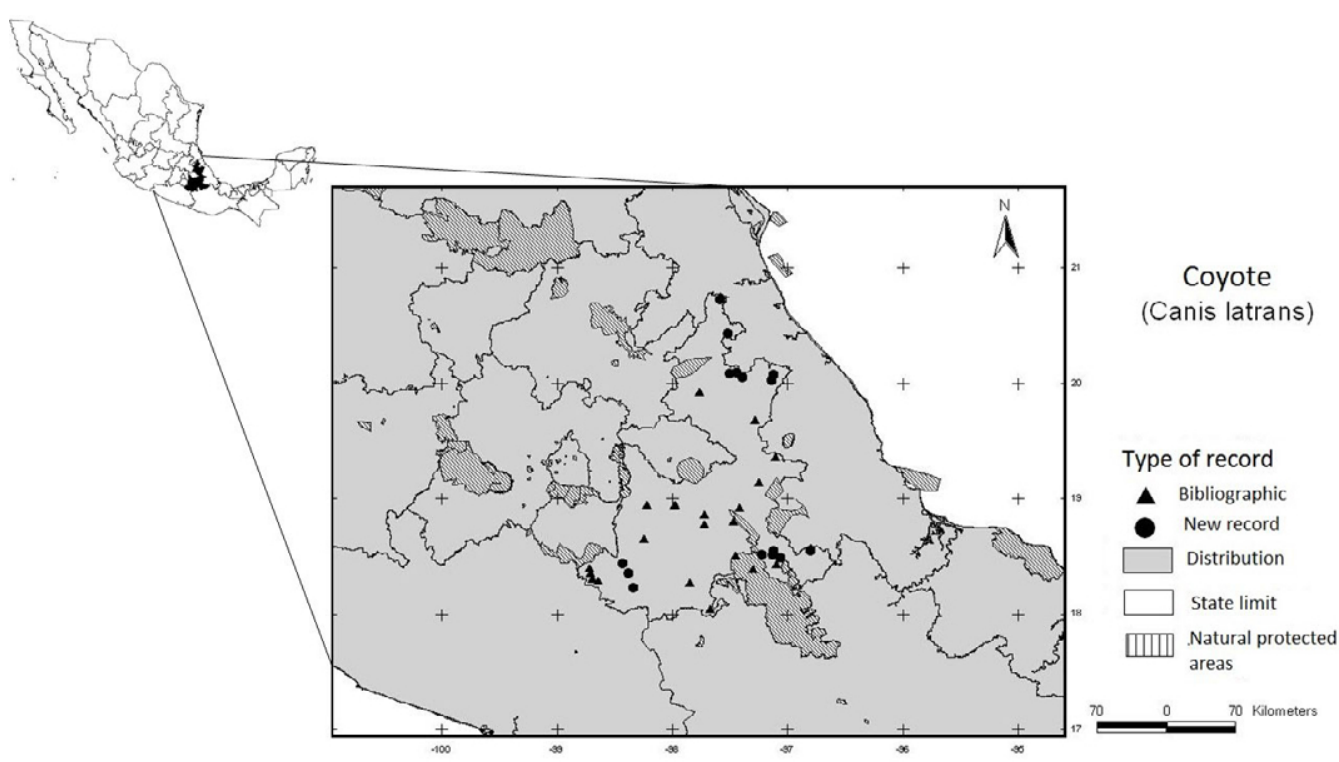

Figure A7. Coyote records in the state of Puebla and distribution obtained from InfoNatura (2007).

skins at a local museum, within the botanical garden named "Helia Bravo Hollis" in Zapotitlán de las Salinas (Tehuacan-Sierra Negra), which are thought to have been hunted in XS with moderate perturbation (Figure A7).

Sign (6): Mixteca, Sierra Norte (2), Tehuacan-Sierra Negra (3). We found tracks and heard vocalizations in Mixteca (near Agua Dorada within TDF). In Sierra Norte we also heard vocalizations near a canyon with TF close to Tuzamapan de Galeana, and found tracks in a ranch close to Villa Lázaro Cárdenas. In Tehuacan-Sierra Negra we found tracks in TDF with XS near the communities San Esteban Necoxcalco, San Antonio Cañada, and Corral Macho; where local people indicated that coyotes might be rare due to a strong poisoning campaign targeted towards feral dogs (Figure $\mathrm{A} 7$ ).

Photographs (4): Mixteca, Sierra Norte (3). We recorded several coyotes in Mixteca and Sierra Norte.
Those near Chiautla de Tapia (Mixteca) were taken in October and December 2010 at a low-use dirt road in TDF. In Sierra Norte, coyotes occurred near communities within patches of TF; in El Tecomote during July 2010, in Vega Chica in May 2010, and in Plan de Guinea in June 2010 (Figure A7).

Aditional records (20): Mixteca (5), Tehuacan-Sierra Negra (2), and Valle (12) Sierra Norte (1). Zacatlán de las Manzanas (Ramírez-Pulido et al. 2005), Acatlán (Ingles 1959); Izúcar de Matamoros (Van Gelder 1960); Atlixco (Jackson 1951); Río Frío (Merriam 1897); Atlixco, Molcaxac, San Baltazar Tetela, Santa María Guadalupe Tecola, Pico de Orizaba, Chiautla ( López-Wilchis and López-Jardines 1999), Santiago Nopala, Ajalpan, San Miguel Zozutla (unpublished data); Molcaxac (unpublished data); Los Humeros (unpublished data); Tlachichuca (unpublished data); Atoyatempan (unpublished data); Chila de las Flores (unpublished 


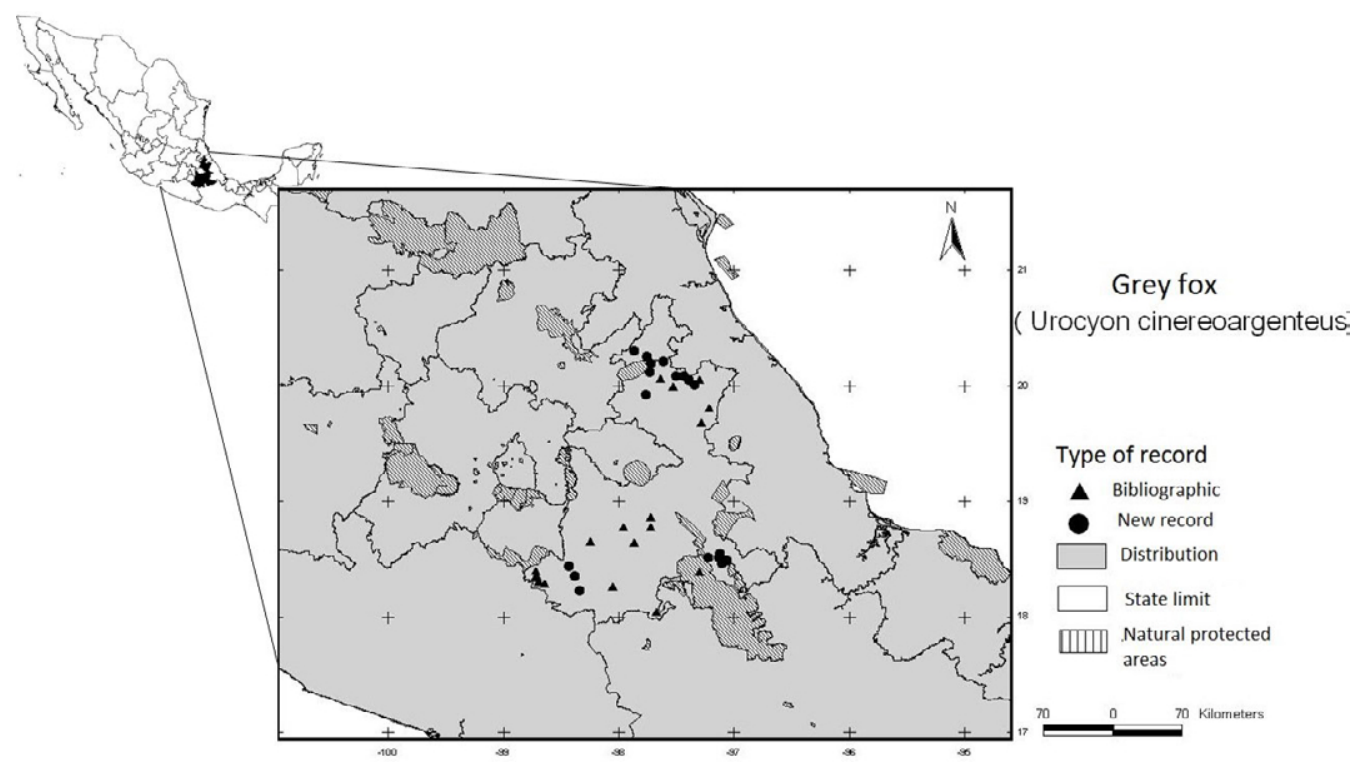

Figure A8. Gray Fox records in the state of Puebla and distribution obtained from InfoNatura (2007).

data); and González Ortega (unpublished unpublished data) (Figure A7).

Urocyon cinereoargenteus (Schreber, 1775)

Common name: Zorra gris, Gray Fox

Direct observation (7): Sierra Norte. We found skins and mounted individuals from forests that varied from $\mathrm{CF}$ to TF in the communities Tuzampan de Galeana, Xicotepec de Júarez, Tlaola, San Pedro Tlaolantongo, Zacatlán de las Manzanas, Olintla, and Tlacuilotepec (Figure A8).

Signs (4): Sierra Norte (2), Tehuacan-Sierra Negra (2). In TF of Sierra Norte we found scats (near Telolotla) and heard vocalizations (near Putaxcat). In Tehuacan-Sierra Negra we found tracks near Tehuacán and Cinco de Mayo within a mosaic of TDF and XS (Figure A8).

Photographs (8): Mixteca (3), Sierra Norte (2), Tehuacan-Sierra Negra (3). We obtained pictures of grey fox in a mix of TDF with XS in communities of Mixteca (Santa Ana Tecolapa, Chiautla de Tapia, and Agua Dorada) and of Tehuacan-Sierra Negra (San Antonio Cañada, Corral Macho, and San Esteban Necoxcalco). In Sierra Norte we obtained pictures in CF near Cuetzalan and TF near Tuxtla. Given the species habits, all pictures were taken indistinctly of time of day and month (Figure A8).

Additional records (12): Mixteca (4), Sierra Norte (2), Tehuacan-Sierra Negra (2), and Valle (4). Zacapala, Zapotitlán delas Salinas, Ocotal, Santiago Yancuictlalpan (Ramírez-Pulido et al. 2005); Izúcar de Matamoros, (Van Gelder 1960); Piaxtla (Goldman 1938; Hall 1981; López-Wilchis and López-Jardines 1999); Molcaxac (unpublished data); Santo Domingo Huehuetlán (unpublished data); Los Húmeros (unpublished data); Atoyatempan (unpublished data); Chila de las Flores (unpublished data); and Zapotitlán Salinas (unpublished data) (Figure A8).
Familia Mustelidae

Taxidea taxus (Schreber, 1778)

Common name: Tejon, Badger

Signs (1): Mixteca. We found digging along the edge of a wall; our findings were corroborated by locals who had seen the species around (Figure A9).

Additional records (3): Valle (3). Acatzingo (RamírezPulido et al. 2005); Texcal (Álvarez and Ocaña 1999), and Chalchicomula (Long 1972) (Figure A9).

\section{Lontra longicaudis (Olfers, 1818)}

Common name: Nutria, Otter

Direct observation (1): Sierra Norte. We found a specimen that was hunted along the river Amixtlan near Villa Lázaro Cárdenas (Figure A10).

Additional records (7): Mixteca (3) and Sierra Norte (4). Venustiano Carranza, Santa Cruz Tejalpa, Jolalpan, Axutla (Gallo Reynoso 1997); Piedras Negras (RamírezPulido et al. 2005); Tuzamapan de Galeana, and Mecapalapa (Ramírez Bravo, 2010) (Figure A10).

\section{Eira barbara (Linnaeus, 1758)}

Common name: Tayra, viejo de monte

Additional records (3): Sierra Norte (2) and TehuacanSierra Negra (1). Zapotitlán de Méndez, Telolotla (Ramírez-Bravo 2011), Coxcatlán (Ramírez-Pulido et al. 2005). We were not able to find any evidence of this species presence. This holds true for previous report, where the observation made by Ramirez-Pulido et al. (2005) corresponds to anecdotal observation while in the area of Coxcatlan (Figure A11). 


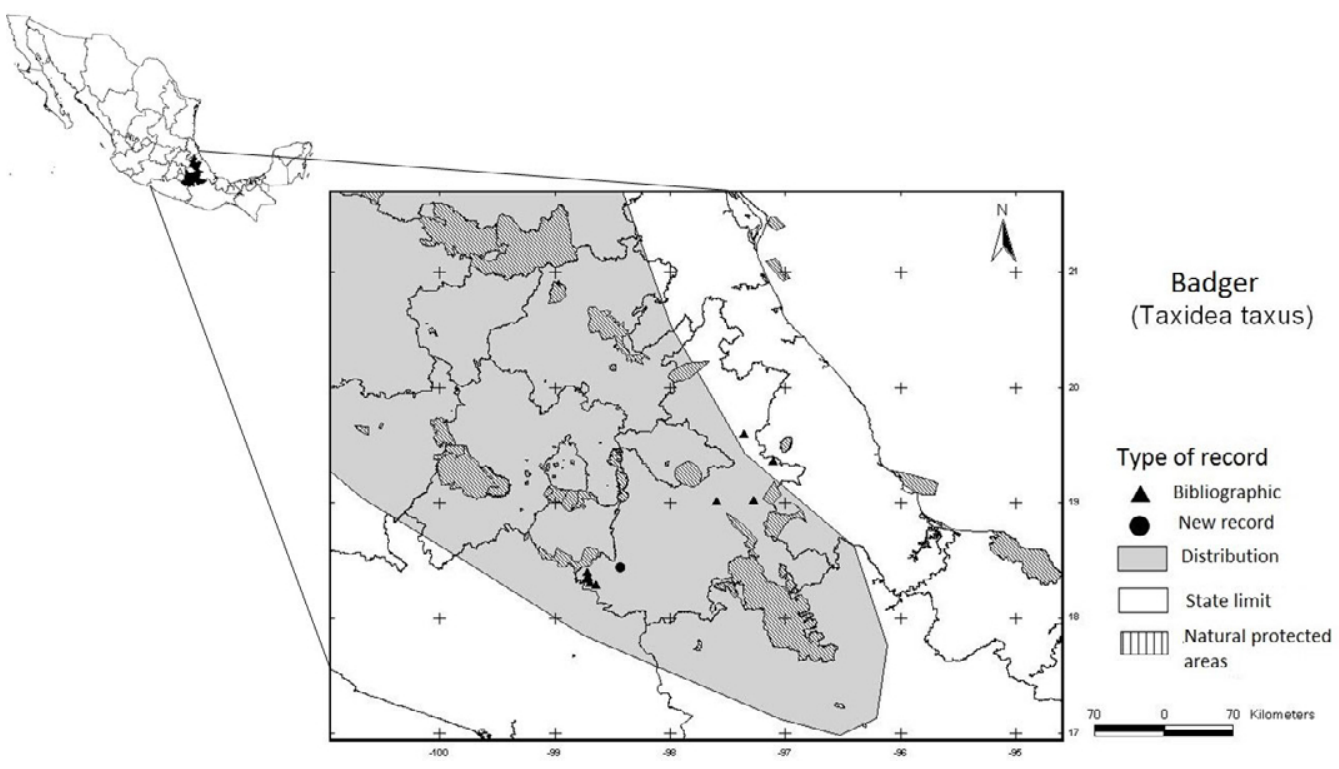

Figure A9. Badger records in the state of Puebla and distribution obtained from InfoNatura (2007).

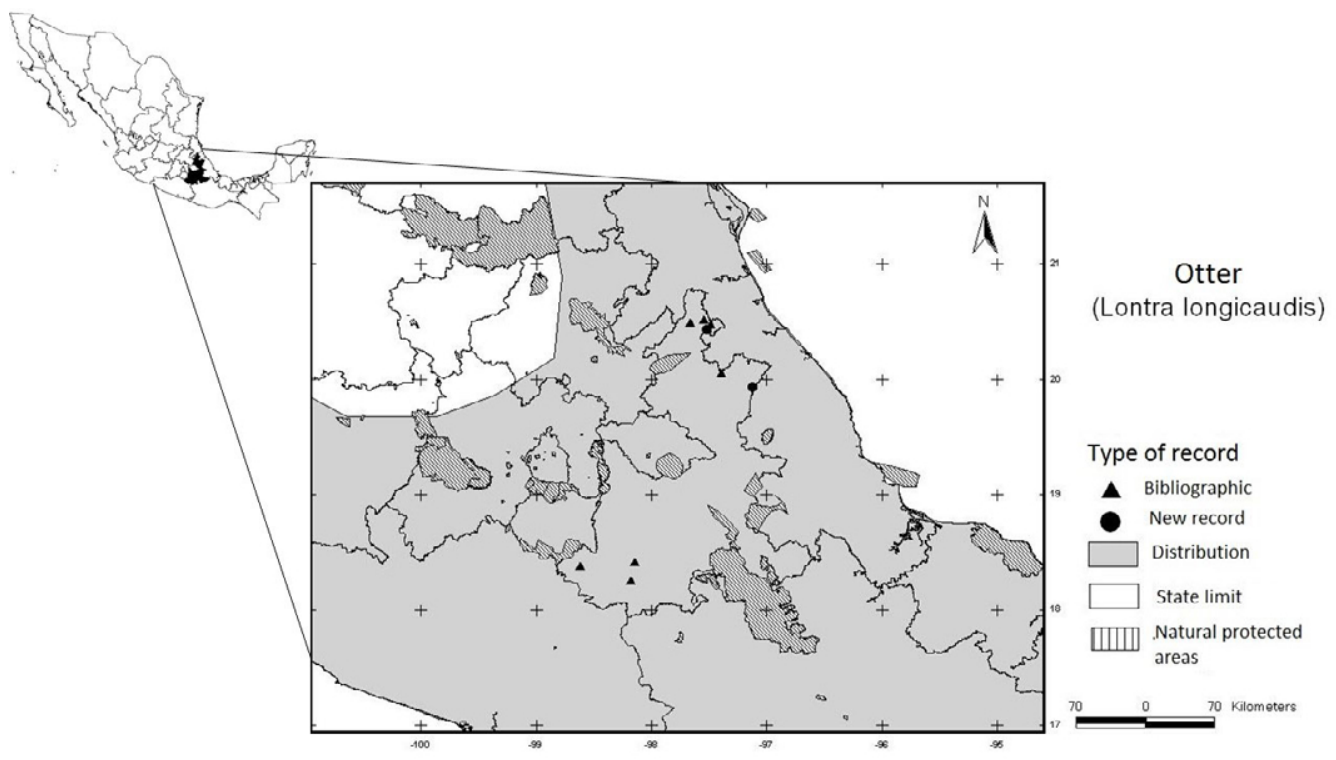

Figure A10. Otter records in the state of Puebla and distribution obtained from InfoNatura (2007).

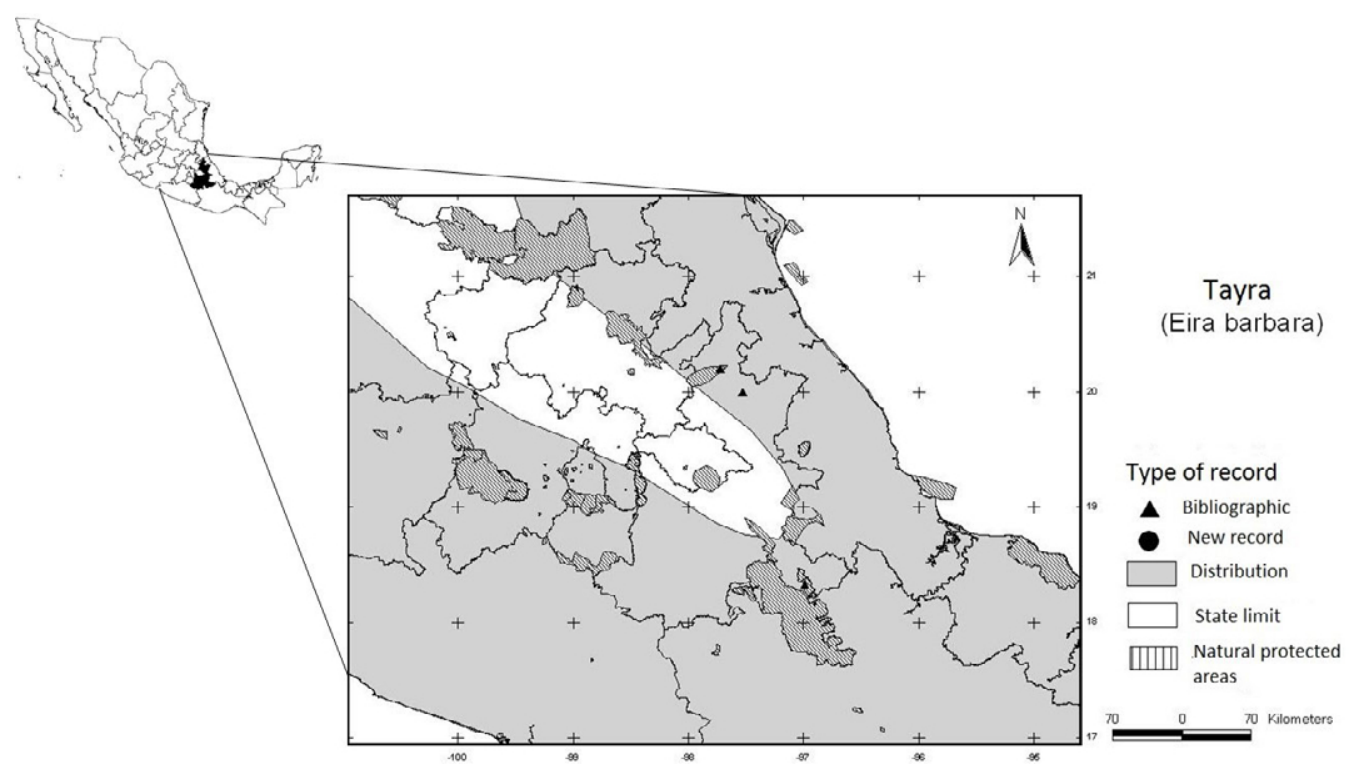

Figure A11. Tayra records in the state of Puebla and distribution obtained from InfoNatura (2007). 


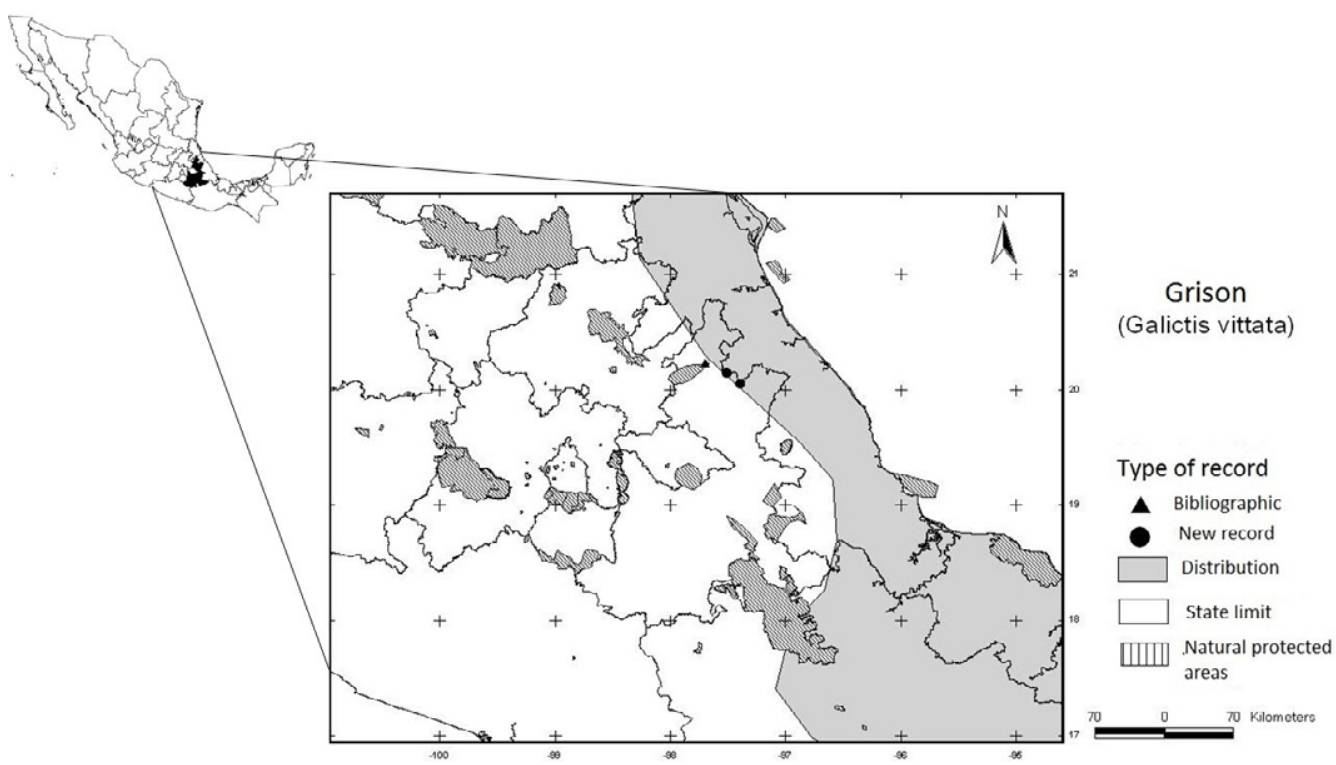

Figure A12. Grison records in the state of Puebla and distribution obtained from InfoNatura (2007).

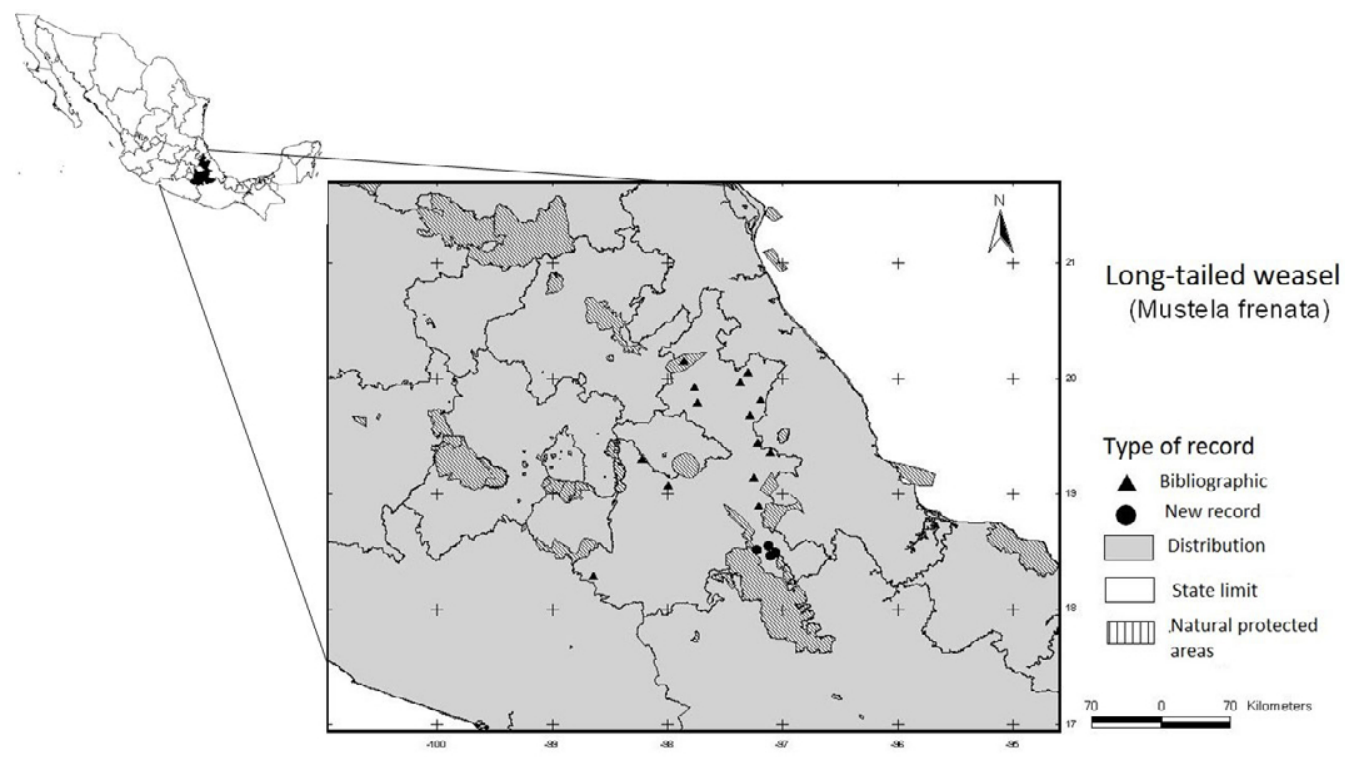

Figure A13. Long-tailed weasel records in the state of Puebla and distribution obtained from InfoNatura (2007).

Galictis vittata (Schreber, 1776)

Common name: Grison

Direct observation (2): Sierra Norte. We found 2 mounted specimens of unknown sex in Tuzamapan. The hunter he found them in a coffee plantation in a canyon from the Tecolutla river. Moreover, in a canyon with TF near Jopala, a male was hunted in April 2010. This specimen was later purchased for a regional dance called "Los Huehues" in the community Vicente Guerrero, where it was later found mummified. Given its unprofessional mummification, most of its hair had been lost, but the remnant hair and shape helped to its identification (Figure A12).

Aditional records (1): Sierra Norte (1). Zihuateutla (Ramírez-Pulido et al. 2005) (Figure A12).
Mustela frenata (Lichtenstein, 1831)

Common name: Comadreja, Long-tailed Weasel

Sign (5): Tehuacan-Sierra Negra. We found tracks in TDF intermixed with XS, close to the communities of Tehuacán, San Antonio Cañada, San Esteban Necoxcalco, Corral Macho, and Colonia Cinco de Mayo (Figure A13).

Additonal records (16): Sierra Norte (5), TehuacanSierra Negra (1), and Valle (9). Aquixtla, San José Alchichica, San Martín Texmelucan, Santiago Yancuictlalpan, Teziutlán, (Ramírez-Pulido et al. 2005); Zacatlán de las Manzanas (Hoffmann et al. 1972; Bassols 1981; Ramírez-Pulido et al. 2005), Huexotitla (Ferrari-Pérez 1886); Los Húmeros (unpublished data); Tlachichuca (unpublished data), Ejido González Ortega (unpublished data); Puebla (Wieczorek 2001); Huauchinango, San 


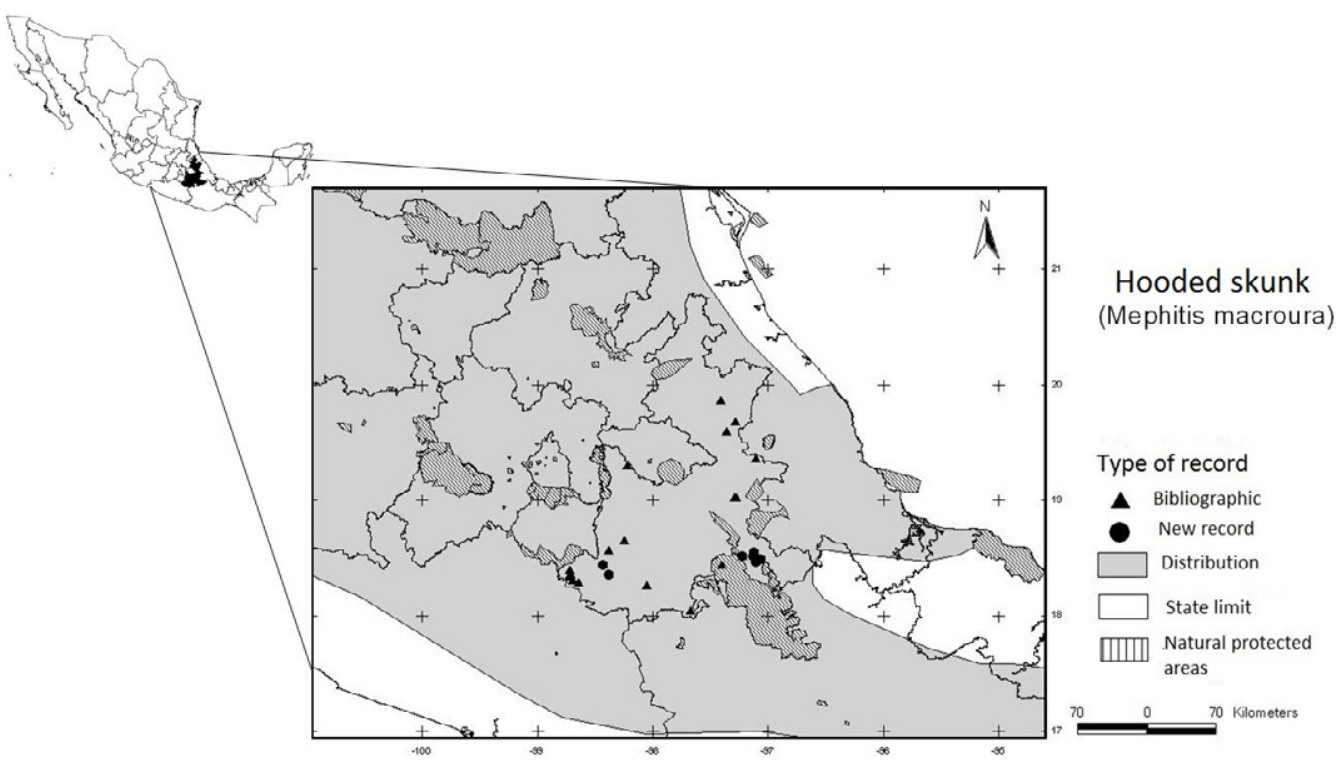

Figure A14. Hooded skunk records in the state of Puebla and distribution obtained from InfoNatura (2007).

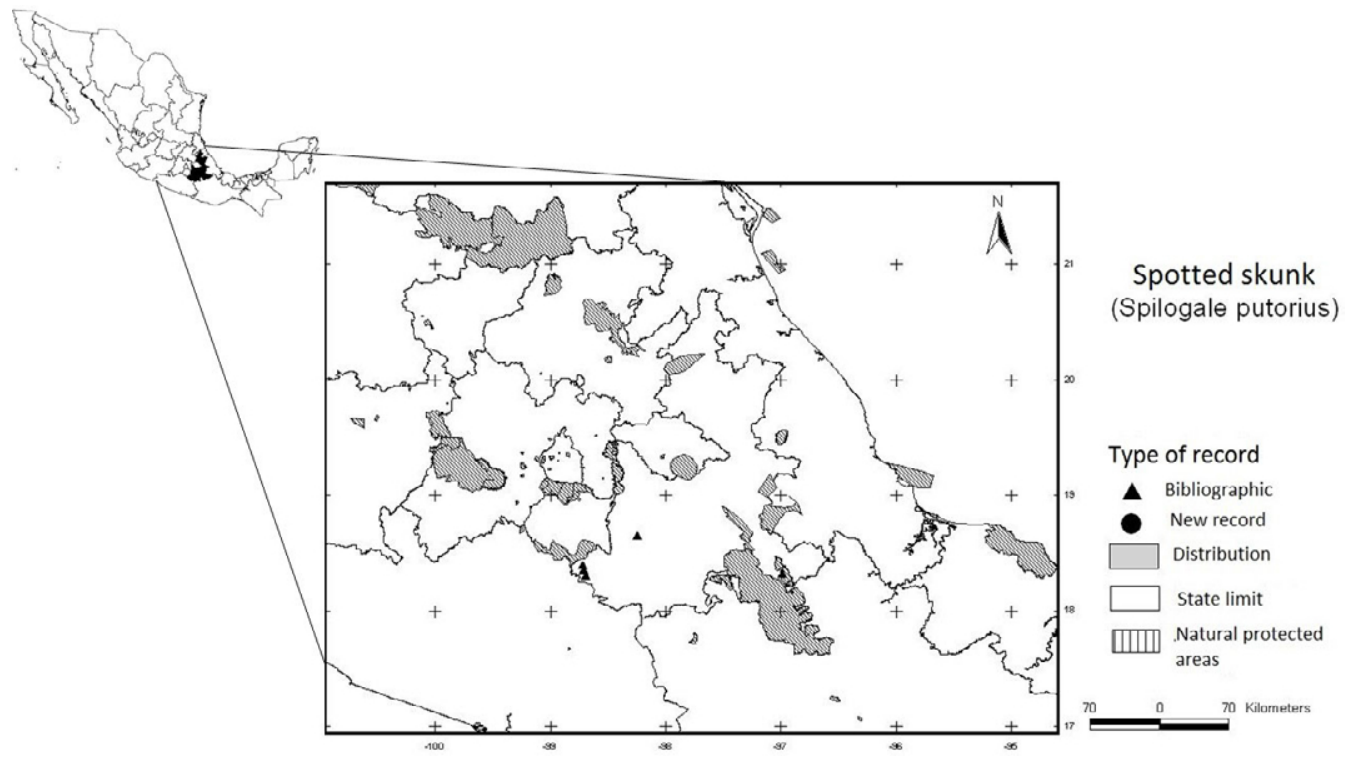

Figure A15. Spotted skunk records in the state of Puebla and distribution obtained from Infonatura.

Martín Texmelucan, Xocoyolo, and Esperanza ( LópezWilchis and López-Jardines 1999) (Figure A13).

Familia Mephitidae

Mephitis macroura (Lichtenstein, 1832) Common name: Zorrillo, Hooded Skunk

Sign (4): Tehuacan-Sierra Negra. We found tracks of M. macroura in TDF intermixed with XS, near the communities San Antonio Cañada, San Diego Chalma, Corral Macho, and Colonia Cinco de Mayo (Figure A14).

Photographs (4): Mixteca (2), Tehuacan-Sierra Negra (2). The camera-trap photographs were taken at night in XS and TDF of Mixteca (near Chiautla de Tapia and Santa Ana Tecolapa) and of Tehuacan-Sierra Negra (near Tehuacán and San Esteban Necoxcalco) (Figure A14).

Additional records (13): Mixteca (4), Sierra Norte (1),
Tehuacan-Sierra Negra (2), and Valle (6). Zacapoaxtla, San Martín Texmelucan, San Andrés, Izúcar de Matamoros, Monte Orizaba, Santa Ana Telostoc, (Ramírez-Pulido et al. 2005), Santa Catarina Cholula; Texcal (Álvarez and Ocaña 1999); Tehuacán (Hall and Dalquest 1950; Hall 1981); Chila de las Flores (unpublished data); Ciudad Serdán, Atencingo, and Piaxtla ( López-Wilchis and López-Jardines 1999) (Figure A14).

\section{Spilogale putorius (Linnaeus, 1758)}

Common name: Zorrillo, Eastern Spotted Skunk

Additonal records (3): Mixteca (1) and Tehuacan-Sierra Negra (2). 5 from Izúcar de Matamóros, (Ramírez-Pulido et al. 2005); Coxcatlán (unpublished data); Izúcar de Matamoros, (Wieczorek 2001); Tepeyolo (Álvarez and Ocaña 1999). We have not been able to find more records for the species (Figure A15). 


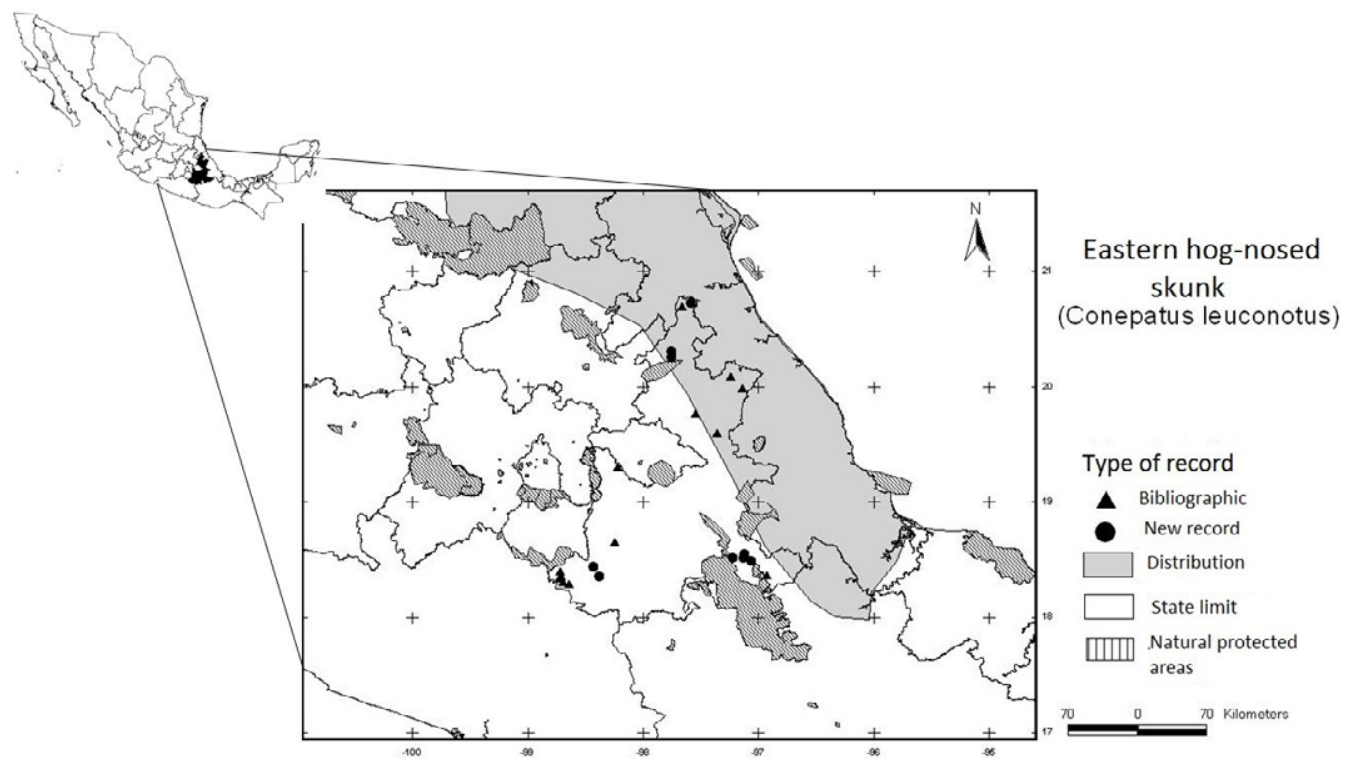

Figure A16. Eastern hog-nosed skunk records in the state of Puebla and distribution obtained from InfoNatura (2007).

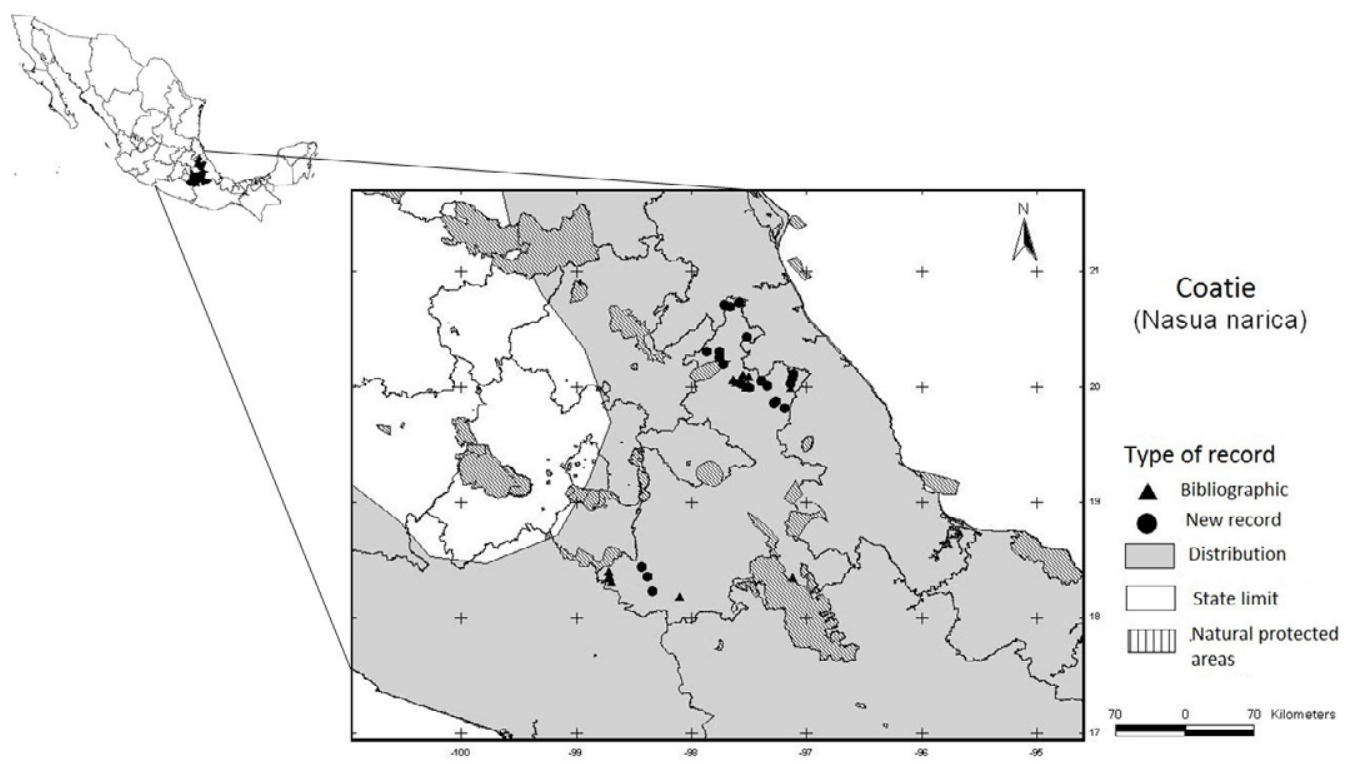

Figure A17. Coatie records in the state of Puebla and distribution obtained from InfoNatura (2007).

Conepatus leuconotus (Lichtenstein, 1832)

Common name: Zorrillo, Eastern Hog-nosed Skunk

Direct observation (1): Sierra Norte. We found a skin from a specimen hunted in a local market in the surroundings of Xicotepec de Júarez. However, the hunter did not give us more information (Figure A16).

Sign (3): Tehuacan-Sierra Negra. We found tracks in patches of XS and TDF near San Esteban Necoxcalco, San Antonio Cañada, and Corral Macho (Figure A16).

Photographs (5): Mixteca (2), Sierra Norte, TehuacanSierra Negra. We camera-trapped them at night: in XS with TF of Mixteca (near Santa Ana Tecolapa, and Chiautla de Tapia). in TF of Sierra Norte (near Las Pilas and El Tecomate), and in XS with TF of Tehuacan-Sierra Negra (near Tehuacan) (Figure A16).

Additional records (9): Mixteca (2), Sierra Norte (3), Tehuacan-Sierra Negra (1), and Valle (3). San Martín Texmelucan, Metlaltoyuca ( López-Wilchis and
López-Jardines 1999); Ayotoxco, Las Margaritas, Guadalupe, San Martín Texmelucan, Izúcar de Matamoros, (Ramírez-Pulido et al. 2005); Tepeyolo, Texcal (Álvarez and Ocaña 1999); and Rancho el Ajenjibre (Warner and Beer 1957; Hall 1981) (Figure A16).

Family Procyonidae

Nasua narica (Linnaeus, 1766)

Common name: Coatié, White-nosed Coati

This is one of the species with the widest distribution and most records in Puebla.

Direct observation (9): Sierra Norte. We found pets, skins, and individuals observed in the wild while conducting fieldwork. In all cases, hunted and pet specimens had been found close to the communities where they were taken (Figure A17).

Photographs (11): Mixteca (3), Sierra Norte (8). 


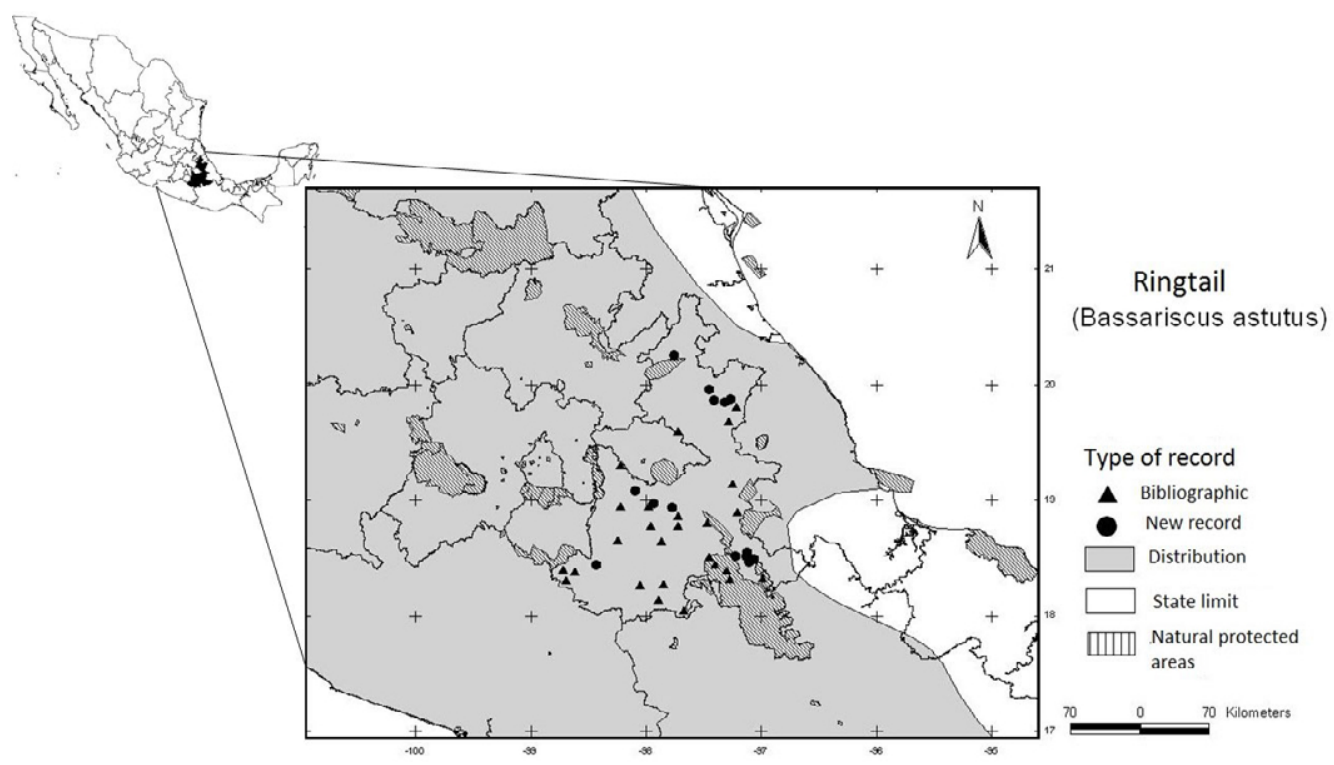

Figure A18. Ringtail records in the state of Puebla and distribution obtained from InfoNatura (2007).

Camera-traps located coati in TF, CF, and throughout the study close to Santa Ana Tecolapa, Chiautla de Tapia, and Agua Dorada; and near Telolotla, El Tecomate, La Ceiba, Vega de Montecelli, Vega Chica, Plan de Guinea, Las Pilas, and Metlaltoyuca, accordingly (Figure A17).

Additional records (10): Mixteca (1), Sierra Norte (8), and Tehuacan-Sierra Negra (1). Bienvenido de Galeana, Olintla, Ocotal, Amixtlán, Hueytlalpan, Las Margaritas, Zapotitlán de Méndez, Tecomatlán (Ramírez-Pulido et al. 2005); Mesa de San Diego (Warner and Beer 1957); and San José Miahuatlán (unpublished data) (Figure A17).

\section{Bassariscus astutus (Lichtenstein, 1830)}

Common name: Cacomixtle norteño, Ringtail

Direct observation (2): Sierra Norte (2), Specimens revised were hunted in Sierra Norte (found in CF near Xicotepec de Júarez and Zacapoaxtla) (Figure A18).

Signs (6): Sierra Norte, Tehuacan-Sierra Negra (5). We found tracks in Sierra Norte (San Diego) or from different communities close to the preserve TehuacanCuicatlan in XS with patches of TDF (Figure A18).

Photographs (3): Mixteca, Sierra Norte (2). Photographed individuals were found during nights in TDF near Santa Ana Tecolapa (Mixteca) or in CF of Sierra Norte (near Tlatlauquitepec and Hueyapan) (Figure A18).

Additonal records (27): Mixteca (8), Tehuacan-Sierra Negra (8), and Valle (11). Izúcar de Matamóros, Chila de las Flores, Jolalpan, Zacapala, Xochiltepec, San Juan Llano Grande (Ramírez-Pulido et al. 2005) Izúcar de Matamóros, (Van Gelder 1960; Hall 1981); Puebla (Ferrari-Pérez 1886); San Miguel Zozutla, Santiago Nopala, Ajalpan, (unpublished data); Molcaxac (unpublished data); Santo Domingo Huehuetlán (unpublished data); Los Humeros (unpublished data); Tlalchichuca, (unpublished data); Atoyatempan, (unpublished data); Zapotitlán de las Salinas; Santa Ana Telostoc, Coxcatlán, (Ramírez-Pulido et al. 2005; Unpublished data); San Martín Texmelucan (López-Wilchis and López-Jardines 1999; Ramírez-Pulido et al. 2005); Acatlán de Osorio, Atlixco, Valsequillo, Piaxtla, San Baltazar Tetela, and Esperanza ( López-Wilchis and López-Jardines 1999) (Figure A18).

\section{Bassariscus sumichastrii (Saussure, 1860)}

Common name: Cacomixtle tropical, Tropical Ringtail

Additional records (1): Mixteca (1). Tehuitzingo ( López-Wilchis and López-Jardines 1999). We have not been able to obtain more records for the species; however, this record alone expands its known distribution $86 \mathrm{~km}$ to the north of its current range, into the Mixteca (Figure A19).

\section{Potos flavus (Schreber, 1774)}

Common name: Martucha, Kinkajou

Direct observation (6): Sierra Norte (5), TehuacanSierra Negra. These were skins and mounted specimens, found in CF near San Marcos Eloxochitlan (TehuacanSierra Negra) and CF near Cuetzalán and Zapotitlán de Méndez (Sierra Norte); and TF from Sierra Norte near El Tecomate, Agua Fría, and Tuzamapan de Galeana (Figure A20).

Additional records (2): Sierra Norte (2). Ocotal and Las Margaritas (Ramírez-Pulido et al. 2005) (Figure A20).

\section{Procyon lotor (Linnaeus, 1758)}

\section{Common name: Mapache, Raccoon}

This is one of the widest spread species in the state because it can be found in different ecosystems.

Direct observation (6): Sierra Norte. These include pets, skins, and individuals observed while conducting 


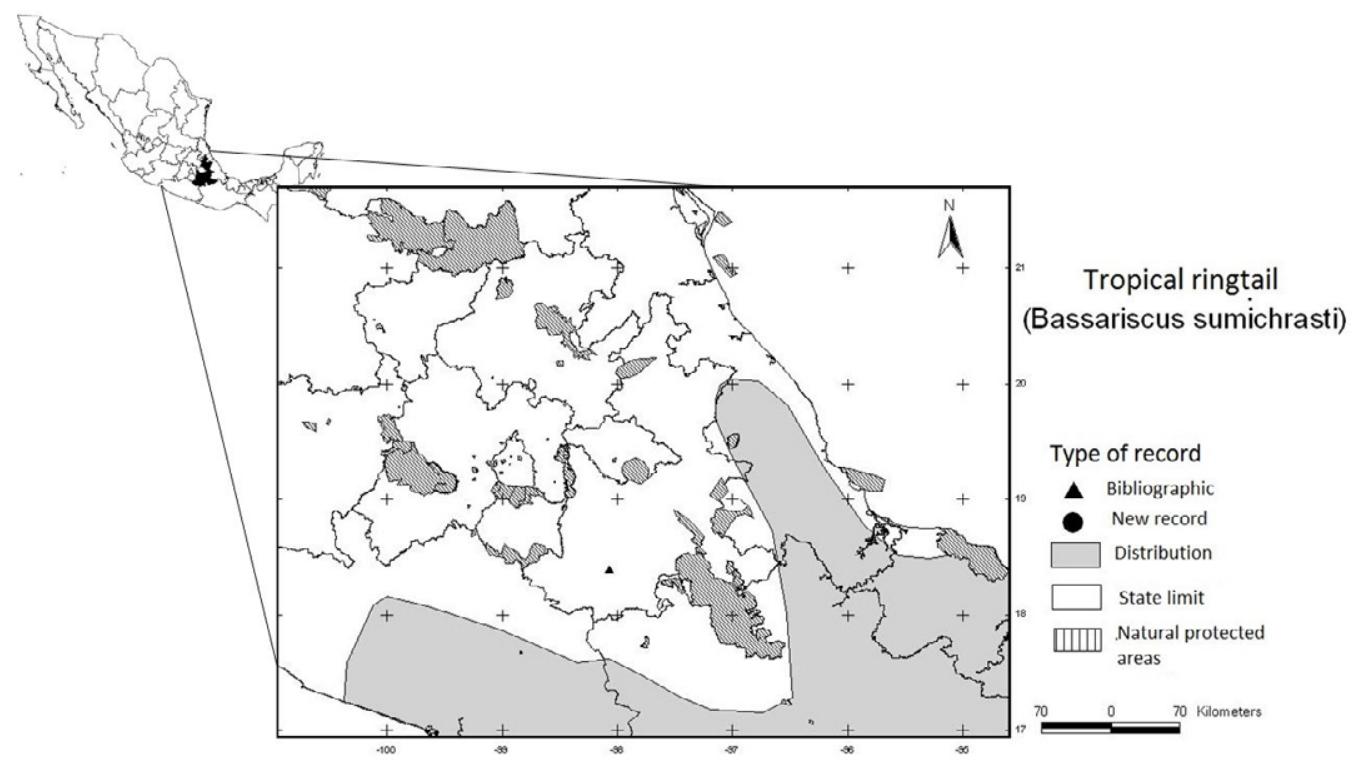

Figure A19. Tropical ringtail records in the state of Puebla and distribution obtained from InfoNatura (2007).

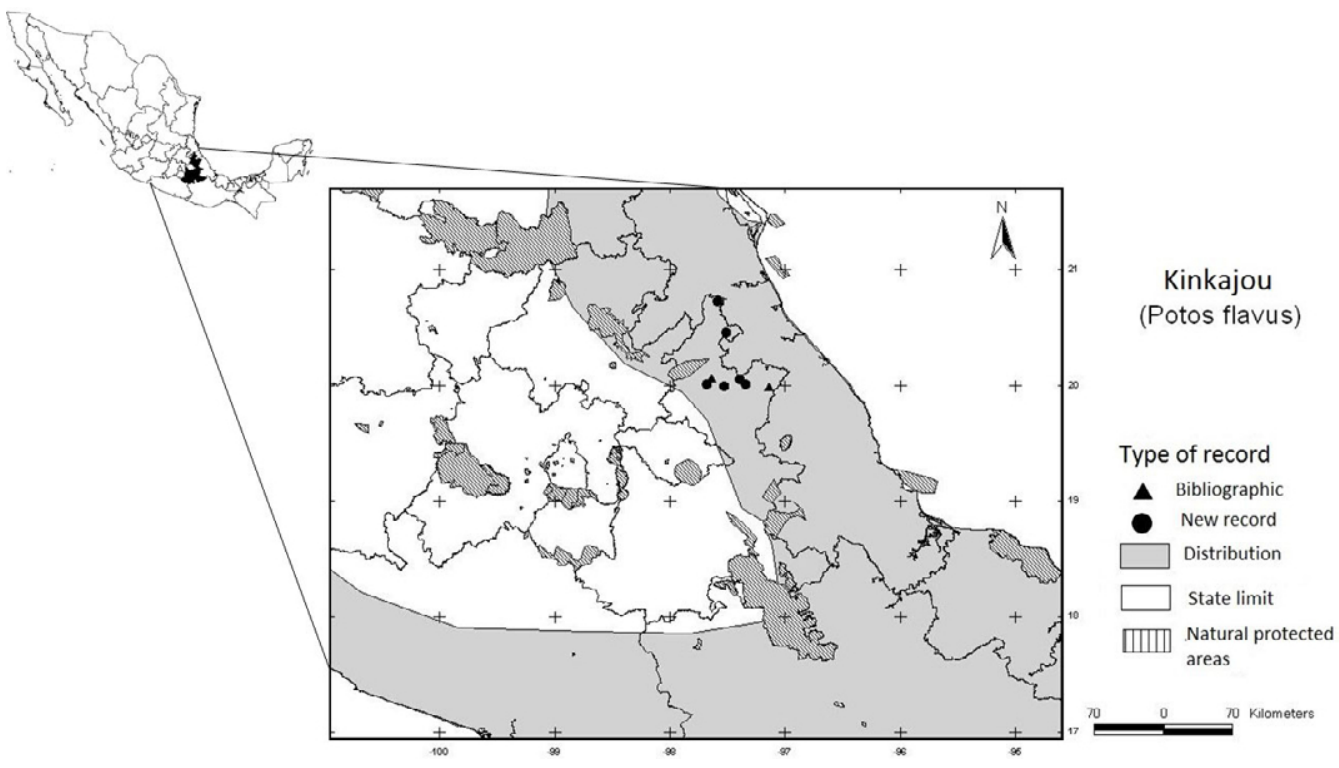

Figure A20. Kinkajou records in the state of Puebla and distribution obtained from InfoNatura (2007).

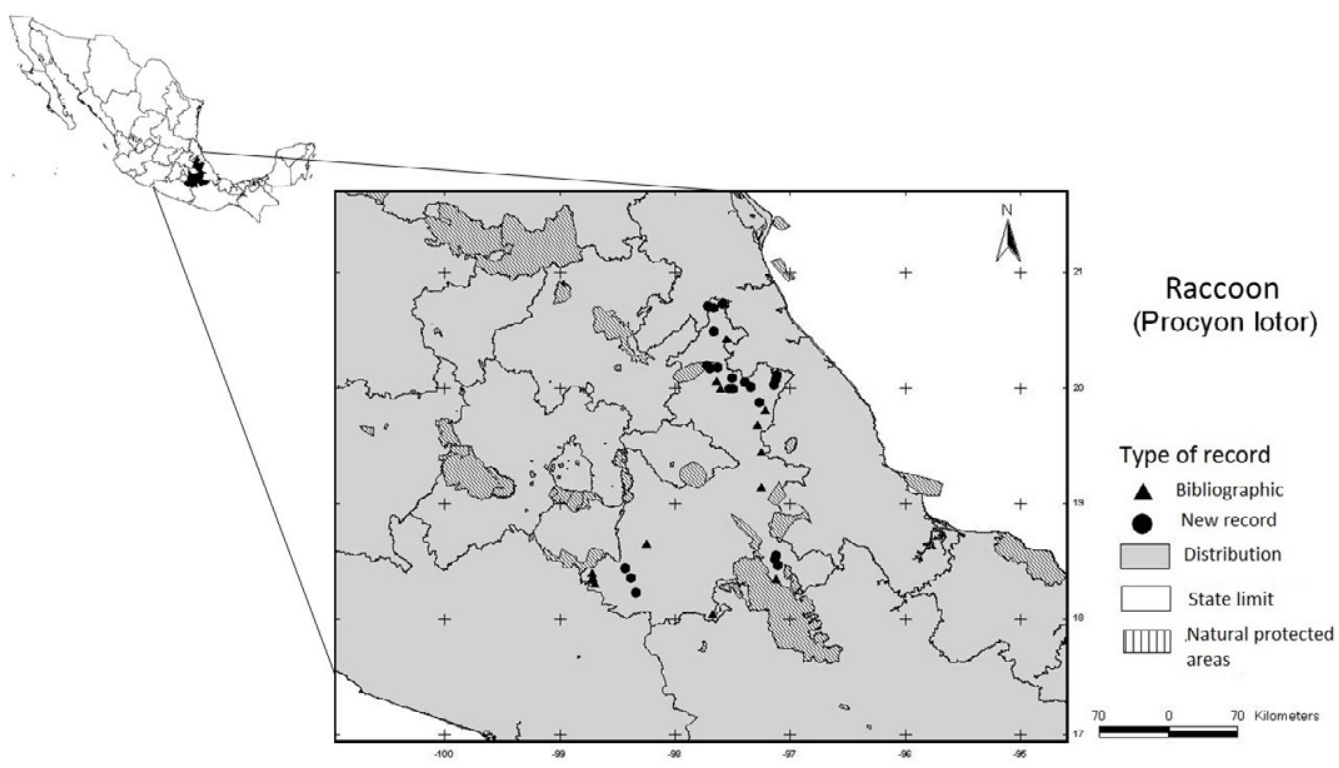

Figure A21. Raccoon records in the state of Puebla and distribution obtained from InfoNatura (2007). 
field work. In all cases, the individuals were found near the communities where they had been captured or hunted (Figure A21).

Sign (5): Sierra Norte (2), Tehuacan-Sierra Negra (3). The former in Hueyapan and Temascalapa the latter in San Antonio Cañada, San Esteban Necoxcalco, and Cinco de Mayo (Figure A21).

Photographs (11): Mixteca (3), Sierra Norte (7), Tehuacan-Sierra Negra The pictures were made in patches of TF and CF as well as TDF forests throughout our study (Figure A21).
Additional records (9): Mixteca (2), Sierra Norte (3), Tehuacan-Sierra Negra (1), and Valle (3). María Andrea, Ocotal, Tepango de Rodríguez, San José Alchichica, (Ramírez-Pulido et al. 2005); Los Humeros (unpublished data); Tlachichuca (unpublished data); Chila de las Flores (unpublished data); San José Miahuatlán (unpublished data); and Izúcar de Matamoros, ( López-Wilchis and López-Jardines 1999; Ramírez-Pulido et al. 2005) (Figure A21). 